\title{
Phosphino Carboxylic Acid Ester Functionalized Carbosilane Dendrimers: Nanoscale Ligands for the Pd-Catalyzed Hydrovinylation Reaction in a Membrane Reactor
}

\author{
Eva B. Eggeling, ${ }^{\dagger}$ Neldes J . Hovestad, J ohann T. B. H. J astrzebski, ${ }^{*}$ Dieter Vogt, ${ }^{, \dagger}$ and \\ Gerard van Koten*,‡
}

Schuit Institute of Catalysis, Laboratory of Inorganic Chemistry and Catalysis, Eindhoven University of Technology, 5600 MB Eindhoven, The Netherlands, and Debye Institute, Department of Metal-Mediated Synthesis, Utrecht University, Padualaan 8, 3584 CH Utrecht, The Netherlands

\section{d.vogt@tuenl}

Received March 22, 2000

\begin{abstract}
Phosphino carboxylic acid ester terminated $\mathrm{G}_{0}$ compounds $\mathrm{Si}\left\{\left(\mathrm{CH}_{2}\right)_{3} \mathrm{SiMe}_{2}\left(\mathrm{C}_{6} \mathrm{H}_{4} \mathrm{CH}_{2} \mathrm{OC}(\mathrm{O})\left(\mathrm{CH}_{2}\right)_{n}\right.\right.$ $\left.\mathrm{CH}_{2} \mathrm{PPh}_{2}\right\}_{4}(\mathbf{9 a}$ and $\mathbf{9 b} ; \mathrm{n}=1,2)$ and the carbosilane dendrimers $\mathrm{Si}\left\{\left(\mathrm{CH}_{2}\right)_{3} \mathrm{Si}\left(\left(\mathrm{CH}_{2}\right)_{3} \mathrm{SiMe}_{2}\left(\mathrm{C}_{6} \mathrm{H}_{4}-\right.\right.\right.$ $\left.\left.\mathrm{CH}_{2} \mathrm{OC}(\mathrm{O})\left(\mathrm{CH}_{2}\right)_{n} \mathrm{CH}_{2} \mathrm{PPh}_{2}\right)_{3}\right\}_{4}(\mathbf{1 0 a}$ and $\mathbf{1 0 b} ; \mathrm{n}=1,2)$ have been prepared as hemilabile nanoscale ligands for the palladium-catalyzed codimerization of ol efins. The hydrovinylation of styrene was carried out in a continuously operated nanofiltration membrane reactor. Under continuous conditions, the selectivity of the reaction is increased considerably. Monomeric model complexes and the dendritic catalysts were compared for their activity and selectivity in batch reactions. The $\mathrm{Pd}$ catalyst complexes were prepared in situ from the dendritic ligands and an (allyl)palladium(II) precursor.
\end{abstract}

\section{Introduction}

It remains a crucial feature for the commercialization of a catalytic process to separate catalysts from the reaction mixture. For most of the applications seen in industry today it was not until an efficient strategy for catalyst recovery was developed that they were used in chemical production. Depending on the productivity of the catalyst, in fine chemicals synthesis the recycling of sophisticated ligands can be as an important economic factor as the separation of the noble metal used. Therefore, there is currently considerable interest in the development of organometallic catalysts anchored on supports such as dendrimers. ${ }^{1-7}$ Taking into account the enormous structural variety of these well-defined large molecules, several potential applications in homogeneous catalysis $^{8-10}$ and supported synthesis ${ }^{11,12}$ have been en-

* Corresponding authors.

† Eindhoven University of Technology.

₹ Utrecht University.

(1) Tomalia, D. A.; Naylor, A. M.; Goddard, W. A.; III. Angew. Chem., Int. Ed. Engl. 1990, 29, 138.

(2) Zeng, F.; Zimmerman, S. C. Chem. Rev. 1997, 97, 1681.

(3) Vögtle, F. Dendrimer Topics in Current Chemistry; SpringerVerlag: Berlin 1998

(4) Gorman, C. Adv. Mater. 1998, 10, 295.

(5) Hearshaw, M. A.; M oss, J. R. Chem. Commun. 1999, 1.

(6) Bosman, A. W.; J anssen, H. M.; Meijer, E. W. Chem. Rev. 1999, 99, 1665.

(7) Hovestad, N. J .; Hoare, J . L. J astrzebski, J . T. B. H.; Smeets, W. J.J .; Canty, A. J .; Śpek, A. L.; van Koten G. Organometallics 1999, $18,2970$.

(8) Knapen. J. W. J .; van der Made, A. W.; De Wilde, J . C.; van Leeuwen, P. W. M. N.; Wijkens, P., Grove, D. M.; van Koten, G. Nature 1994, 372, 659 .

(9) Reetz, M. T.; Lohmer, G.; Schwickardi, R. Angew. Chem., Int. Ed. Engl. 1997, 36, 1526.

(10) Gossage, R. A.; J astrzebski J . T. B. H.; van Ameijde, J .; Mulders, S. J . E.; Brouwer, A. J .; Liskamp, R. M. J .; van Koten, G. Tetrahedron Lett. 1999, 40, 1413.

(11) Kim, R. M.; Manna, M.; Hutchins, S. M.; Griffins, P. R.; Yates, N. A.; Bernick, A. M.; Chapman, K. T. Proc. Natl. Acad. Sci. U.S.A., 1996, 93, 10012. visaged, and several groups have started to explore the potential of functionalized dendritic materials. Because of their nanoscopic size these molecularly enlarged dendritic compounds have the potential to be removed from the product mixture via ultra- or nanofiltration techniques. ${ }^{13-15}$

C-C-coupling reactions that offer the opportunity to convert cheap carbon feedstocks into valuable chemical compounds are of high current interest. Major interest focuses on homogeneous catalytic versions with their adjustable regio- and stereoselectivity. ${ }^{16}$

For example, the hydrovinylation reaction (the codimerization with ethylene) of olefins opens easy access to building blocks for fine chemicals. ${ }^{17}$ Since the first report of a hydrovinylation reaction with a $\mathrm{RhCl}_{3}$ catalyst, ${ }^{18}$ several metals were used as catalysts in hydrovinylation reactions, ${ }^{19-20}$ among which nickel ${ }^{21-25}$ and palladium ${ }^{26-28}$ were the most successful ones.

(12) Hovestad, N. J .; J astrzebski, J . T. B. H.; van Koten, G. Polym. Mater. Sci. Eng. 1999, 80, 53.

(13) Kragl, U.; Dreisbach, C. Angew. Chem., Int. Ed. Engl. 1996, 35, 642 .

(14) Brinkmann, N.; Giebel, D.; Lohmer, G.; Reetz, M. T.; Kragl, J . Catal. 1999, 183, 163.

(15) Hovestad, N. J .; Eggeling, E. B.; Heidbüchel, H. J .; J astrzebski, J . T. B. H.; Kragl, U.; Keim, W.; Vogt, D.; van Koten, G. Angew. Chem., Int. Ed. Engl. 1999, 38, 1655.

(16) Beller, M.; Bolm, C., Eds.; Transition Metals for Organic Synthesis; Wiley-VCH: New York, 1998.

(17) J olly, W.; Wilke, G. In Applied homogeneous catalysis with organometallic compounds; Cornils, B.; Herrmann, W. A., Eds.; VCH: New York, 1992; pp 1024.

(18) Alderson, T.; J enner, E. L.; Lindsey, R. V. J r. J . Am. Chem. Soc. 1965, 87, 5638 .

(19) Umezaki, H.; Fujiwara, Y.; Sawara, K.; Teranishi, S. Bull. Chem. Soc. J pn. 1973, 46, 2230.

(20) Pillai, S. M.; Tembe, G. L.; Ravindranathan, M. J . Mol. Catal. $1993,84,77$.

(21) Bogdanovic, B.; Henc, B.; Karmann, H.-G.; Nüssel, H.-G.; Walter, D.; Wilke, G. Ind. Eng. Chem. 1970, 62, 35. 1973. 


\section{Scheme 1. Hydrovinylation of Styrene and Side Reactions}

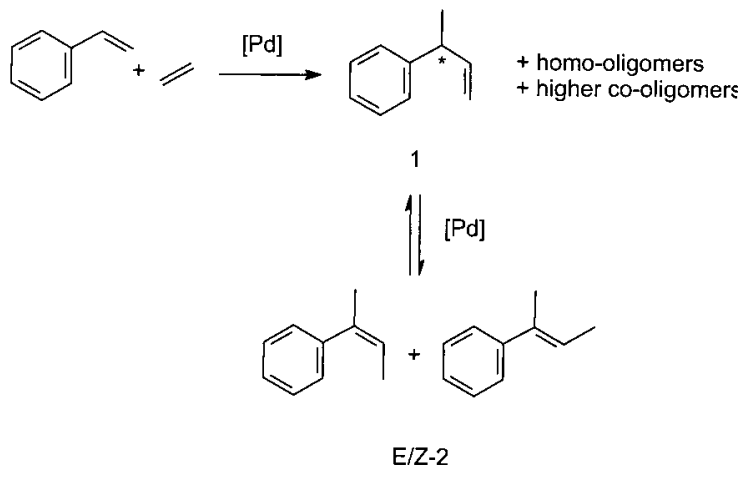

In case of nickel, a nickel halide salt activated by a Lewis acid together with a chiral azaphosphol ene ligand reported by Wilke is still the most efficient system for this reaction. ${ }^{29}$ But progress has been made recently: RajanBabu et al. obtained good results using hemilabile MOP ligands. By use of a weakly coordinating counteranion, the Lewis acid could be replaced. ${ }^{30,31} \mathrm{Via}$ a similar route, Leitner et al. were able to apply the successful Wilke-system in supercritical $\mathrm{CO}_{2}$, yielding promising results also in view of an immobilization of the catalyst. ${ }^{32}$

In case of palladium, for sufficient activity the halide has to be abstracted by a silver salt of a noncoordinating anion resulting in a cationic palladium complex. Due to their lower reactivity, the use of palladium catalysts allows moderate reaction conditions between $0{ }^{\circ} \mathrm{C}$ and room temperature. We could obtain good results in the asymmetric hydrovinylation of styrene (Scheme 1) using a ligand bearing a stereogenic phosphorus atom as well when applying bulky $\alpha$-chiral (R)-tricarbonyl ( $\eta^{6}$-ethylbenzene)-chromium complexes as asymmetric ligands. ${ }^{33,34}$ Recently, the chiral benzylcyclohexylphenylphosphine has been reported by Muller et al. to catalyze the hydrovinylation of styrene with moderate selectivities and the hydrovinylation of 2-vinylnaphthalene with good selectivities. ${ }^{35}$

It is known that phosphino carboxylic acid derivatives lead to efficient and selective catalytic systems for C-C coupling reactions. ${ }^{36}$ In the hydrovinylation of styrene

(23) Kitatsume, S.; Otaba, S. J pn. Kokai Tokkyo KohoJ P 61 91,138, 1986; Chem. Abstr. 1986, 105, 227505d.

(24) Nozima, H.; Kawata, N.; Nakamura, Y.; Maruya, K.; Mizoroki, T.; Ozaki, A. Chem. Lett. 1973, 1163. 127.

Ceder, R.; Muller, G.; Ordinas, J . I. J . Mol. Catal. 1994, 92

(26) Barlow, M. G.; Bryant, M. J .; Hazeldine, R. N.; Mackie, A. G. J . Organomet. Chem. 1970, 21, 215.

(27) Kawamoto, K.; Imanaka, T.; Teranishi, S. Bull. Chem. Soc. J pn. $1970,43,2512$

(28) Hattori, S.; Munakata, H.; Tatsuoka, K.; Shimizu, T. US Pat. 3,803,254, 1974.

(29) Wilke, G. Angew. Chem. 1988, 100, 189

(30) Nomura, N.; J in, J .; Park, H.; Rajanbabu, T. V. J . Am. Chem. Soc. 1998, 120, 459-460.

(31) RajanBabu, T. V.; Nomura, N.; J in, J .; Radetich, B.; Park, H .; Nandi, M. Chem. Eur. J. 1999, 5, 1963-8.

(32) Wegner, A.; Leitner, W. Chem. Commun. 1999, 16, 1583.

(33) Bayersdörfer, R.; Ganter, B.; Englert, U.; Keim, W.; Vogt, D.

J . Organomet. Chem. 1998, 552, 187-194.

(34) Englert, U.; Haerter, R.; Vasen, D.; Salzer, A.; Eggeling, E. B.; Vogt, D. Organometallics 1999, 18, 4390.

(35) Albert, J .; Cadena, J . M.; Granell, J .; Muller, G.; Ordinas, J . I.; Panyella, D.; Puerta, C.; Sañudo, C.; Valerga, P. Organometallics 1999, $18,3511$. 430.

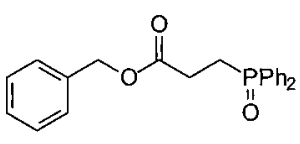

3a

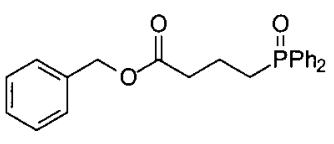

$3 b$
Figure 1.

high activity and selectivity toward 3-phenyl but-1-ene $\mathbf{1}$ were observed applying various phosphino esters. ${ }^{37}$

However, at higher conversions isomerization of the product to internal achiral olefins E/ Z-2 takes place. Therefore, it would be useful to be able to run the reaction continuously at lower conversion.

Herein we report on the synthesis of dendritic carbosilanes ${ }^{38}$ functionalized with various diphenylphosphino carboxylic acid ester end groups. These dendritic hemilabile ligands were applied in the palladium-catalyzed hydrovinylation of styrene. The new Pd catalysts derived from $G_{0}$ compounds and $G_{1}$ dendritic $P, O$ ligands are relatively stable under the reaction conditions, compared to similar complexes of monodentate ligands that decompose rapi dly after formation to give pal ladium black. F or the first time, the hydrovinylation was carried out continuously in a pressure membrane reactor using a nanofiltration membrane, giving rise to the selective formation of the desired, chiral 3-phenylbut-1-ene $\mathbf{1}$

\section{Results and Discussion}

Synthesis and Characterization of Model and Dendritic Ligands. Model studies were undertaken to determine the most efficient reaction conditions for periphery functionalization of the dendritic support. Coupling of benzylic alcohol with phosphinoxy carboxylic acid chlorides $\mathrm{ClC}(\mathrm{O})\left(\mathrm{CH}_{2}\right)_{n} \mathrm{CH}_{2} \mathrm{P}(\mathrm{O}) \mathrm{Ph}_{2}(\mathrm{n}=1,2)^{39}$ in the presence of 4-(dimethylamino)pyridine in DMF afforded compounds $\mathbf{3 a}$ and $\mathbf{3 b}$ (Figure $\mathbf{1}$ ).

Compound $\mathbf{3 a}$ is a colorless crystalline solid, and $\mathbf{3 b}$ is a slightly yellow viscous oil. Both were isolated in good yields (57-95\%). The ${ }^{1} \mathrm{H}$ NMR spectrum of 3 a shows a multiplet for the methylene protons $\mathrm{C}(\mathrm{O})\left(\mathrm{CH}_{2}\right)_{2} \mathrm{P}(\mathrm{O}) \mathrm{Ph}_{2}$ at $2.65 \mathrm{ppm}$, and the ${ }^{1} \mathrm{H}$ NMR spectrum of $\mathbf{3 b}$ shows three well-resolved resonances at 2.00, 2.37, and $2.52 \mathrm{ppm}$. The ${ }^{13} \mathrm{C}$ and ${ }^{31} \mathrm{P}$ NMR spectra show the respective resonances at the expected chemical shifts. The GC-MS spectra of 3a and 3 b show $\mathrm{M}^{+}$peaks at respectively 364 and 378 mass units.

The compound $\mathrm{Si}\left\{\left(\mathrm{CH}_{2}\right)_{3} \mathrm{SiMe}_{2}\left(\mathrm{C}_{6} \mathrm{H}_{4} \mathrm{CH}_{2} \mathrm{OH}\right)\right\}_{4}, \mathrm{G}_{0^{-}}$ $(\mathrm{OH})_{4}(4)$, and first generation carbosilane dendrimer $\mathrm{Si}$ $\left\{\left(\mathrm{CH}_{2}\right)_{3} \mathrm{Si}\left(\left(\mathrm{CH}_{2}\right)_{3} \mathrm{SiMe}_{2}\left(\mathrm{C}_{6} \mathrm{H}_{4} \mathrm{CH}_{2} \mathrm{OH}\right)\right)_{3}\right\}_{4}, \mathrm{G}_{1}-(\mathrm{OH})_{12}$ (5), have been used as inert support material. Coupling of the carbosilane supports 4 and 5 with $\mathrm{ClC}(\mathrm{O})\left(\mathrm{CH}_{2}\right)_{n}$ $(\mathrm{CH})_{2} \mathrm{P}(\mathrm{O}) \mathrm{Ph}_{2}(\mathrm{n}=1,2)$, under the same conditions as described above, resulted in the formation of $G_{0}$ phosphine oxides $\mathbf{6} \mathbf{a}, \mathbf{b}$ and dendritic $\mathrm{G}_{1}$ phosphine oxides $\mathbf{7 a} \mathbf{a}, \mathbf{b}$ as viscous oils, which were isolated in $43-85 \%$ yield (Schemes 2 and 3).

The methylene protons of the $\mathrm{SiCH}_{2} \mathrm{CH}_{2} \mathrm{CH}_{2} \mathrm{Si}$ units appear as three well-resolved resonances for the $\mathrm{G}_{0}$

(37) Britovsek, G. J . P. Ph.D. Thesis, RWTH Aachen, Germany, 1993.

(38) Majoral, J.-P.; Caminade, A.-M. Chem. Rev. 1999, 99, 845-880.

(39) (a) Tsvetkov, E. N.; Bondarenko, N. A.; Malakhova, I. G.; Kabachnik, M. I. Synthesis 1986, 198-208. 
Scheme $2^{\mathrm{a}}$
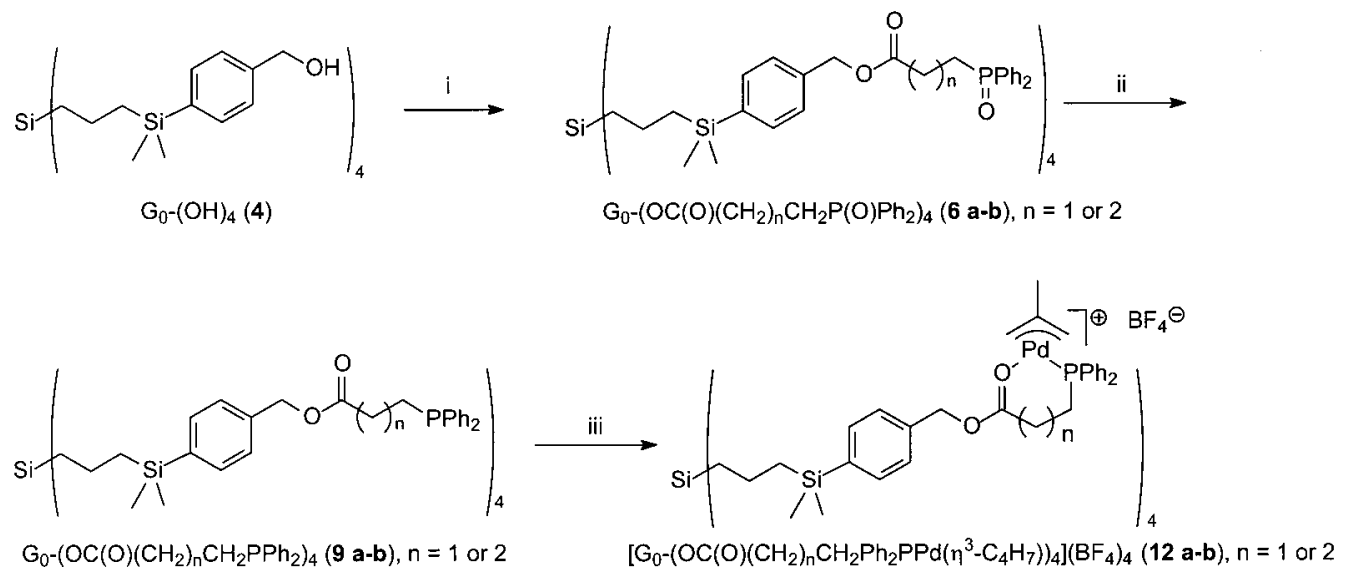

a Reagents and conditions: (i) 6.0 equiv. $\mathrm{Ph}_{2} \mathrm{P}(\mathrm{O}) \mathrm{CH}_{2}\left(\mathrm{CH}_{2}\right)_{\mathrm{n}} \mathrm{C}(\mathrm{O}) \mathrm{Cl}$, 4-(dimethylamino)pyridine, DMF, $23{ }^{\circ} \mathrm{C}, 16 \mathrm{~h}$; (ii) $\mathrm{HSiCl}_{3}, \mathrm{NEt}_{3}$, benzene, reflux, $17 \mathrm{~h}$. (iii) $\left[\left(\eta^{3}-\mathrm{C}_{4} \mathrm{H}_{7}\right) \mathrm{Pd}(\mathrm{cod})\right] \mathrm{BF}_{4}, \mathrm{CH}_{2} \mathrm{Cl}_{2}, 0{ }^{\circ} \mathrm{C}, 1 \mathrm{~h}$.

\section{Scheme $3^{a}$}
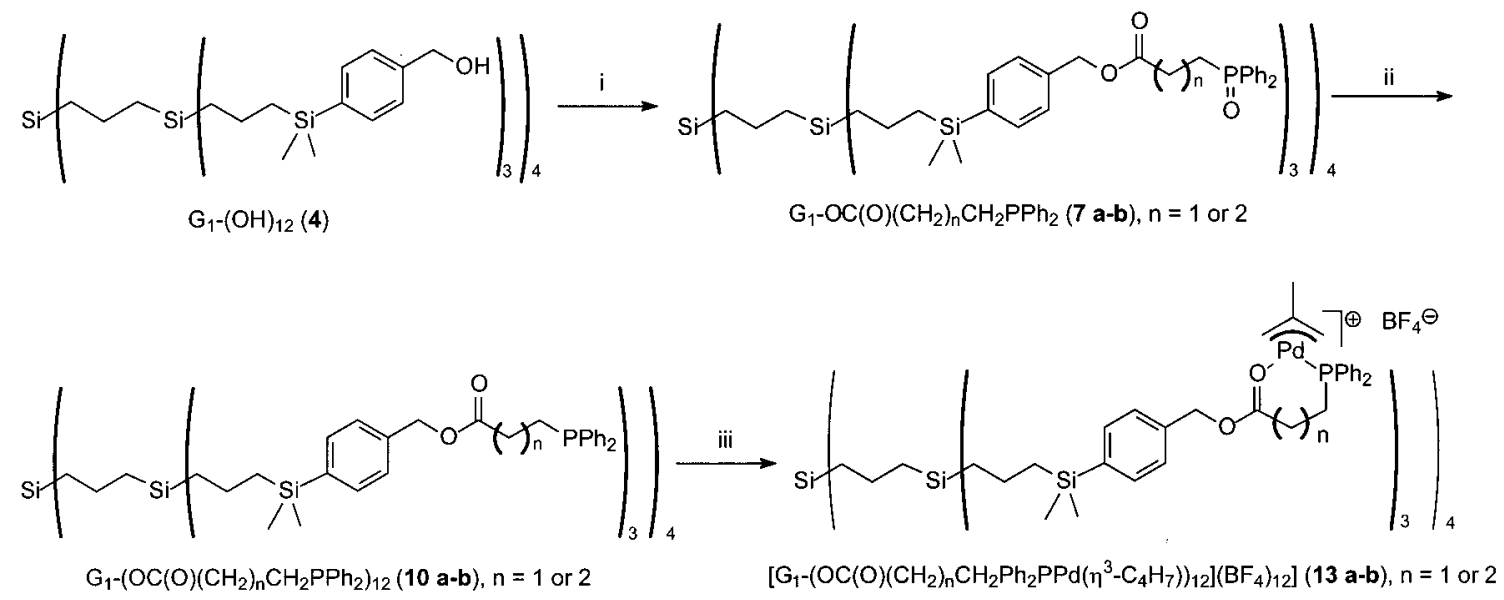

a Reagents and conditions: ( $\mathrm{i}-\mathrm{iii}$ ) following similar procedures to those used for the synthesis of $\mathbf{6 a}, \mathbf{b}$ in Scheme 2.

compound $(24 \mathrm{H})$ as well as for the $\mathrm{G}_{1}$ dendrimer $(96 \mathrm{H})$. In the ${ }^{13} \mathrm{C}\left\{{ }^{1} \mathrm{H}\right\}$ NMR spectra of $\mathbf{7 a}$ and $\mathbf{7 b}$ two of the inner core methylene carbons of the $\mathrm{G}_{1}$ dendrimer are visible while the third resonance occurs together with resonances of one of the outer methylene carbons. MALDITOF-MS spectra of $\mathbf{7 a}$ and $\mathbf{7 b}$ show signals at $\mathrm{m} / \mathrm{z}$ 5974.1 and 6142.6 corresponding to $\left[\mathrm{G}_{1-}-\left(\mathrm{OC}(\mathrm{O})\left(\mathrm{CH}_{2}\right)_{2^{-}}\right.\right.$ $\left.\left.\mathrm{P}(\mathrm{O}) \mathrm{Ph}_{2}\right)_{12}+\mathrm{Agg}\right]^{+}(\mathrm{calcd} 5974.2)$ and $\left[\mathrm{G}_{1^{-}}\left(\mathrm{OC}(\mathrm{O})\left(\mathrm{CH}_{2}\right)_{3^{-}}\right.\right.$ $\left.\mathrm{P}(\mathrm{O}) \mathrm{Ph}_{2}\right)_{12}+\mathrm{IAg}^{+}(\mathrm{calcd} 6142.4)$, respectively. A solution of silver(I) trifluoroacetate in THF was added to the samples in order to improve the peak resolution.

The model compounds $\mathbf{3} \mathbf{a}, \mathbf{b}$ and the phosphine oxides $\mathbf{6} \mathbf{a}, \mathbf{b}$ and $\mathbf{7 a}, \mathbf{b}$ were converted into the phosphino compounds $\mathbf{8 a}, \mathbf{b}, \mathbf{9 a}, \mathbf{b}$, and $\mathbf{1 0 a}, \mathbf{b}$, respectively, by reduction with trichlorosilane in benzene.

The ${ }^{1} \mathrm{H}$ NMR spectra of the reduced compounds show no significant shift of the benzylic protons. The aromatic regions of the phosphino compounds $\mathbf{8 a}, \mathbf{b}, \mathbf{9 a}, \mathbf{b}$, and 10a,b show one multiplet. The ${ }^{31} \mathrm{P}\left\{{ }^{1} \mathrm{H}\right\} N \mathrm{~N}$ R spectra of the phosphino compounds $\mathbf{8 a}, \mathbf{b}, \mathbf{9 a}, \mathbf{b}$, and $\mathbf{1 0 a}, \mathbf{b}$ confirm that quantitative reaction has occurred as indicated by a shift of the phosphorus resonance to higher field, i.e., from 30 to -16 ppm. The FAB-MS spectra of compounds 9a and $\mathbf{9 b}$ show signals at $\mathrm{m} / \mathrm{z} 1850$ and 1889 corresponding to $\left[\mathrm{G}_{0^{-}}\left(\mathrm{OC}(\mathrm{O})\left(\mathrm{CH}_{2}\right)_{2} \mathrm{PPh}_{2}\right)_{4}+2 \mathrm{O}\right]^{+}(\mathrm{calcd} 1851)$ and $\left[\mathrm{G}_{0}-\left(\mathrm{OC}(\mathrm{O})\left(\mathrm{CH}_{2}\right)_{3} \mathrm{PPh}_{2}\right)_{4}+1 \mathrm{O}\right]^{+}(\mathrm{calcd} 1889)$, respec- tively. Due to their air sensitivity, no elemental analysis of the phosphines could be obtained.

The model and dendritic catalysts were prepared in situ by treatment of the ligands with equimolar amounts of $\left[\left(\eta^{3}-\mathrm{C}_{4} \mathrm{H}_{7}\right) \mathrm{Pd}(\mathrm{cod})\right] \mathrm{BF}_{4}$ (cod = 1,5-cyclooctadiene) or $\left[\left(\eta^{3}-\mathrm{C}_{3} \mathrm{H}_{5}\right) \mathrm{Pdl}\right]_{2} / \mathrm{AgSbF}_{6}$.

Catalytic Hydrovinylation of Styrene. High selectivity to the codimers was observed when the resulting catalysts $\mathbf{8 a}, \mathbf{b}, \mathbf{9 a}, \mathbf{b}$, and $\mathbf{1 0 a}, \mathbf{b}$ were applied in batch reactions (Table 1 ).

The ligands derived from diphenyl phosphino propionic acid $(n=1)$ forming a six-membered hemilabile $P d(P \wedge O)$ chelate ring were generally less active than their diphenylphosphino butyric acid analogues $(n=2)$ forming a seven-membered hemilabile $\mathrm{Pd}(\mathrm{P} \wedge \mathrm{O})$ chelate ring (8a vs $\mathbf{8 b}$, entries 1 and $5 ; \mathbf{9 a}$ vs $\mathbf{9 b}$, entries 3 and $8 ; \mathbf{1 0 a}$ vs 10b, entries 4 and 10). The differences in activity are supposed to be due to the higher lability of the sevenmembered chelate ring, which makes the catalysts more active.

The monomeric model compounds $\mathrm{PhCH}_{2} \mathrm{OC}(\mathrm{O}) \mathrm{CH}_{2-}$ $\left(\mathrm{CH}_{2}\right)_{n} \mathrm{PPh}_{2}(\mathrm{n}=1,2)$ showed a much higher activity than the corresponding $\mathrm{G}_{0}$ and $\mathrm{G}_{1}$ dendritic phosphino esters (compare $\mathbf{8 a}, \mathbf{9 a}$, and $\mathbf{1 0 a}$, entries 2, 3, and 4; as well as $\mathbf{8 b}, \mathbf{9 b}$, and $\mathbf{1 0 b}$, entries 5, 6, and 9). This effect might be due to increasing steric hindrance at the catalytic 
8860 J. Org. Chem., Vol. 65, No. 26, 2000

Eggeling et al.

Table 1. Hydrovinylation of Styrene: Comparison of Dendritic Ligands and Model Compounds

\begin{tabular}{|c|c|c|c|c|c|c|}
\hline entry & ligand & $t(h)$ & $\operatorname{conv}^{\mathrm{b}}(\%)$ & yieldc (\%) & $\mathrm{S}_{(\mathbf{1}+\mathbf{2})}{ }^{\mathrm{d}}(\%)$ & $\mathrm{S}_{(\mathbf{1})}^{\mathrm{e}}(\%)$ \\
\hline 1 & $\mathrm{C}_{6} \mathrm{H}_{5} \mathrm{CH}_{2} \mathrm{OC}(\mathrm{O})\left(\mathrm{CH}_{2}\right)_{2} \mathrm{PPh}_{2}(\mathbf{8 a})$ & 3 & 20 & 14 & 73 & 98 \\
\hline 2 & $\mathrm{C}_{6} \mathrm{H}_{5} \mathrm{CH}_{2} \mathrm{OC}(\mathrm{O})\left(\mathrm{CH}_{2}\right)_{2} \mathrm{PPh}_{2}(\mathbf{8 a})$ & 17 & 97 & 50 & 91 & 56 \\
\hline 3 & $\mathrm{G}_{0}-\mathrm{OC}(\mathrm{O})\left(\mathrm{CH}_{2}\right)_{2} \mathrm{PPh}_{2}(9 \mathrm{a})$ & 17 & 68 & 57 & 97 & 86 \\
\hline 4 & $\mathrm{G}_{1}-\mathrm{OC}(\mathrm{O})\left(\mathrm{CH}_{2}\right)_{2} \mathrm{PPh}_{2}(\mathbf{1 0 a})$ & 17 & 1 & 1 & 97 & 93 \\
\hline 5 & $\mathrm{C}_{6} \mathrm{H}_{5} \mathrm{CH}_{2} \mathrm{OC}(\mathrm{O})\left(\mathrm{CH}_{2}\right)_{3} \mathrm{PPh}_{2}(\mathbf{8 b})$ & 3 & 100 & 4 & 93 & $<1$ \\
\hline 6 & $\mathrm{G}_{0}-\mathrm{OC}(\mathrm{O})\left(\mathrm{CH}_{2}\right)_{3} \mathrm{PPh}_{2}(\mathbf{9 b})$ & 3 & 3 & 3 & 95 & 100 \\
\hline 7 & $\mathrm{G}_{0}-\mathrm{OC}(\mathrm{O})\left(\mathrm{CH}_{2) 3} \mathrm{PPh}_{2}(\mathbf{9 b})\right.$ & 10 & 40 & 36 & 97 & 94 \\
\hline 8 & $\mathrm{G}_{0}-\mathrm{OC}(\mathrm{O})\left(\mathrm{CH}_{2}\right)_{3} \mathrm{PPh}_{2}(\mathbf{9 b})$ & 17 & 100 & $<1$ & 92 & $<1$ \\
\hline 9 & $\mathrm{G}_{1}-\mathrm{OC}(\mathrm{O})\left(\mathrm{CH}_{2) 3} \mathrm{PPh}_{2}(\mathbf{1 0 b})\right.$ & 3 & 2 & 1 & nd & 100 \\
\hline 10 & $\mathrm{G}_{1}-\mathrm{OC}(\mathrm{O})\left(\mathrm{CH}_{2}\right)_{3} \mathrm{PPh}_{2}(\mathbf{1 0 b})$ & 17 & 72 & 57 & 100 & 89 \\
\hline
\end{tabular}

a Conditions: $\mathrm{T}=23^{\circ} \mathrm{C}$; initial pressure 30 bar; $\mathrm{P} / \mathrm{Pd}=1$; styrene/Pd $=700, \mathrm{CH}_{2} \mathrm{Cl}_{2}(20 \mathrm{~mL})$, styrene $(4 \mathrm{~mL} ; 34.8 \mathrm{mmol})$. ${ }^{\mathrm{b}} \mathrm{Conversion}$

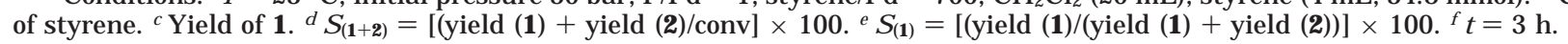

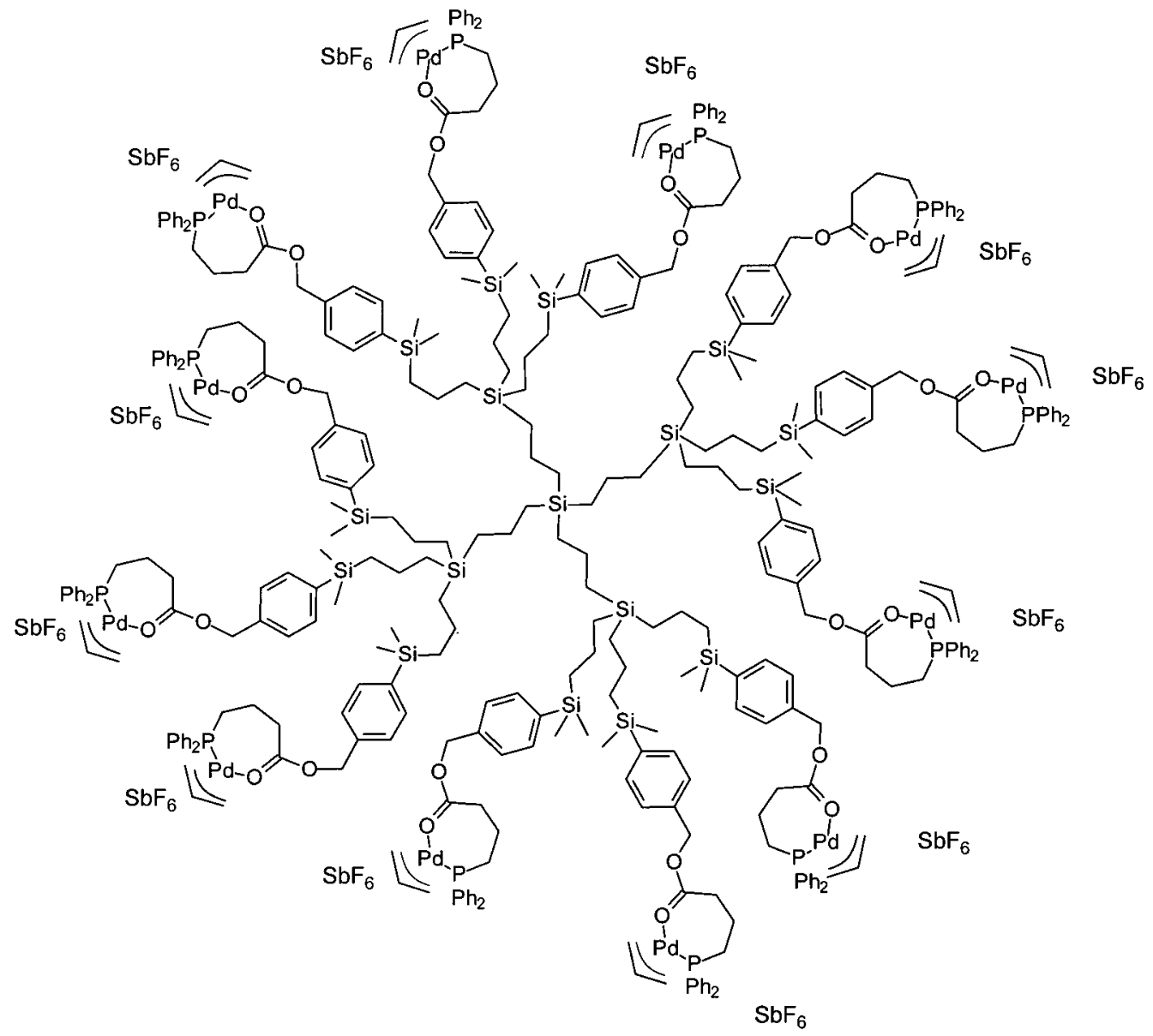

Figure 2. Dendritic catalyst complex 13b with ligand $\mathrm{G}_{1}-\left(\mathrm{OC}(\mathrm{O})\left(\mathrm{CH}_{2}\right)_{3} \mathrm{PPh}_{2}\right)_{12}(\mathbf{1 0 b})$.

sites, making access more difficult when going to higher generations. But also an special dendritic effect must be taken into account, leading to enhanced catalyst deactivation. Because of the close proximity of a large number of palladium centers, the formation of palladium black could be facilitated.

For the ligands derived from diphenylphosphino butyric acid $\mathbf{8 b}$ and $\mathbf{9 b}(\mathrm{n}=2)$ complete conversion and almost complete isomerization of 3-phenyl but-1-ene $\mathbf{1}$ to the E/ Z mixture of achiral 2-phenylbut-2-ene E/ Z-2 was observed within 3 and $17 \mathrm{~h}$, respectively (entries 5 and 8). However, as the isomerization is a consecutive reaction that with the phosphino carboxylic acid ester type of ligands occurs only at considerably high conversion, it can be efficiently suppressed by limiting the conversion (entry 7). This result suggests running the reaction at lower conversion in a continuously operating reactor.
As a result of the stability of the six-membered chelate ring, the $G_{0}$ and $G_{1}$ dendritic ligands $9 a$ and $10 a$ showed only little activity in the hydrovinylation reaction. On the other hand, ligands $\mathbf{9 b}$ and $\mathbf{1 0 b}$ were active enough to be tested in the continuous catalysis.

Therefore the next step was to run the catalysis in a continuously operated high-pressure-membrane-reactor with the new dendritic phosphine Pd catalysts derived from $\mathbf{9 b}$ and $\mathbf{1 0 b}$. For the continuous catalysis a membrane reactor was used which has been developed especially for reactions under high pressure (see Figure 2). In preceding experiments the retention defined as $\mathrm{R}=$ 1 - [permeate]/[retentate]\} of the model compound $\mathrm{G}_{0^{-}}$ $\left(\mathrm{OSi}(\mathrm{Me})_{2}\left({ }^{\mathrm{t}} \mathrm{Bu}\right)\right)_{4}$ in the membrane reactor was determined to be $\mathrm{R}=85 \%$. Although this retention is still far from being sufficient for practical purposes, the results of the catalysis using the dendritic Pd catalyst derived 
Table 2. Hydrovinylation of Styrene: $G_{0}$ and Dendritic Ligands in a Continuous Process

\begin{tabular}{cccccc}
\hline entry & ligand & $\begin{array}{c}\text { conv } \\
(\%)^{b}\end{array}$ & $\begin{array}{c}\text { yield } \\
(\%)^{c}\end{array}$ & $\begin{array}{c}\mathrm{S}_{(\mathbf{1}+\mathbf{2})} \\
(\%)^{d}\end{array}$ & $\begin{array}{c}\mathrm{S}_{(\mathbf{1})} \\
(\%)^{\mathrm{e}}\end{array}$ \\
\hline 1 & $\mathrm{G}_{0}-\mathrm{OC}(\mathrm{O})\left(\mathrm{CH}_{2}\right)_{3} \mathrm{PPh}_{2}(\mathbf{9 b})^{\mathrm{f}}$ & 8.1 & 7.6 & 96 & 98 \\
2 & $\mathrm{G}_{1}-\mathrm{OC}(\mathrm{O})\left(\mathrm{CH}_{2}\right)_{3} \mathrm{PPh}_{2}(\mathbf{1 0 b})^{\mathrm{g}}$ & 40 & 27 & 80 & 85
\end{tabular}

a Conditions: $\mathrm{T}=23^{\circ} \mathrm{C} ; \mathrm{p}=30$ bar; $\mathrm{P} / \mathrm{Pd}=1$; flow rates: ethene solution $2.5 \mathrm{~mL} \mathrm{~h}^{-1}(10 \mathrm{M})$, styrene solution $2.5 \mathrm{~mL} \mathrm{~h}^{-1}$ (1.8 M), MPF-60 NF membrane (Koch Int., Düsseldorf, Germany. ${ }^{b}$ Conversion of styrene. ${ }^{c}$ Yield of $\mathbf{1} .^{d} S_{(\mathbf{1}+2)}=[($ yield $(\mathbf{1})+$ yield $(\mathbf{2}) /$ conv $] \times 100$. ${ }^{e} \mathrm{~S}_{(\mathbf{1})}=[($ yield $(\mathbf{1}) /($ yield $(\mathbf{1})+$ yield $(\mathbf{2}))] \times 100$. ${ }^{\mathrm{f}} \mathrm{t}=9 \mathrm{~h} .{ }^{\mathrm{g}} \mathrm{t}=8 \mathrm{~h}$.

\section{Chart 1. Continuous Hydrovinylation of Styrene in a Membrane Reactor Using Ligand $\mathrm{G}_{0}-\left(\mathrm{OC}(\mathrm{O})\left(\mathrm{CH}_{2}\right)_{3} \mathrm{PPh}_{2}\right)_{4}(9 \mathrm{~b})^{\mathrm{a}}$}

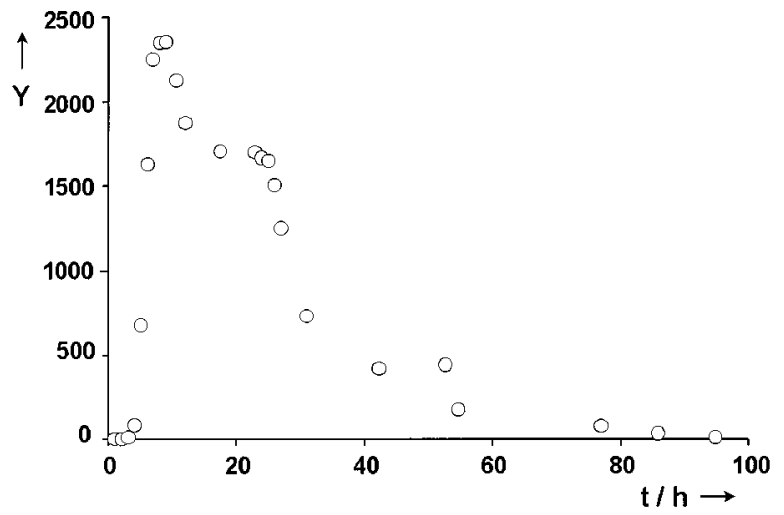

a Conditions: $\mathrm{T}=23{ }^{\circ} \mathrm{C}, \mathrm{p}=30 \mathrm{bar}, 0.05 \mathrm{mmol} \mathrm{Pd}, \mathrm{L} / \mathrm{Pd}=1$, flow rates: ethylene solution $2.5 \mathrm{~mL} \mathrm{~h}^{-1}(10 \mathrm{M})$, styrene solution $2.5 \mathrm{~mL} \mathrm{~h}^{-1}(1.8 \mathrm{M}), \tau=4 \mathrm{~h}, \mathrm{MPF}-60 \mathrm{NF}$ membrane (Koch Int., Düsseldorf, Ger.). Y) space time yield ( $\left.\mathrm{mg} \mathrm{L}^{-1} \mathrm{~h}^{-1}\right)$.

from ligand $\mathrm{G}_{0^{-}}\left(\mathrm{OC}(\mathrm{O})\left(\mathrm{CH}_{2}\right)_{3} \mathrm{PPh}_{2}\right)_{4}$ 9b look promising (Table 2, entry 1, Chart 1). It should be noted that the actual catalyst is al ready much larger $\left(\mathrm{M}_{\mathrm{w}}=2867.97 \mathrm{~g}\right.$ $\left.\mathrm{mol}^{-1}\right)$ than the model compound $4\left(\mathrm{M}_{\mathrm{w}}=1314.62 \mathrm{~g}\right.$ $\mathrm{mol}^{-1}$ ). Chart 1 shows the space-time yield as a function of time for a continuous run with the catalyst derived from $\mathrm{G}_{0}-\left(\mathrm{OC}(\mathrm{O})\left(\mathrm{CH}_{2}\right)_{3} \mathrm{PPh}_{2}\right)_{4} \mathbf{9 b}$.

It takes about $9 \mathrm{~h}$ before the system reaches its maximum productivity of $2.3 \mathrm{~g} \mathrm{~L}^{-1} \mathrm{~h}^{-1}$. The constant decline after the maximum cannot exclusively be explained by the moderate retention of the catalyst: with a residence time of $\tau=4 \mathrm{~h}$ after $80 \mathrm{~h}$, at least $20 \%$ of the catalyst should remain in the reactor. The effect of the washout is amplified by the deactivation of the catalyst visible by the precipitation of palladium black on the surface of the membrane. Although the catalyst possesses an acceptable stability in the batch reaction at low catalyst loading, palladium black formation is favored under continuous conditions.

However, al though the retention of the $\mathrm{G}_{0}$ compound is modest, the desired 3-phenylbut-1-ene $\mathbf{1}$ was produced over a period of $80 \mathrm{~h}$. Most important is the observation that hardly any isomerization or other side products could be detected in the product solution (Table 2 , entry 1).

Under these conditions using a $\mathrm{G}_{0}-\mathrm{Pd}_{4}$ catalyst and a continuous reaction mode, highly selective conversion is achieved, though the yields are quite low due to the decreased activity of this catalyst. Like in the continuous catalysis, a significant induction period is also found in the batch reaction (see Chart 2). The length of this period,

\section{Chart 2. Induction Period in Batch Reaction Using $\mathrm{G}_{0}-\left(\mathrm{OC}(\mathrm{O})\left(\mathrm{CH}_{2}\right)_{3} \mathrm{PPh}_{2}\right)_{4}(9 \mathrm{~b})^{\mathrm{a}}$}

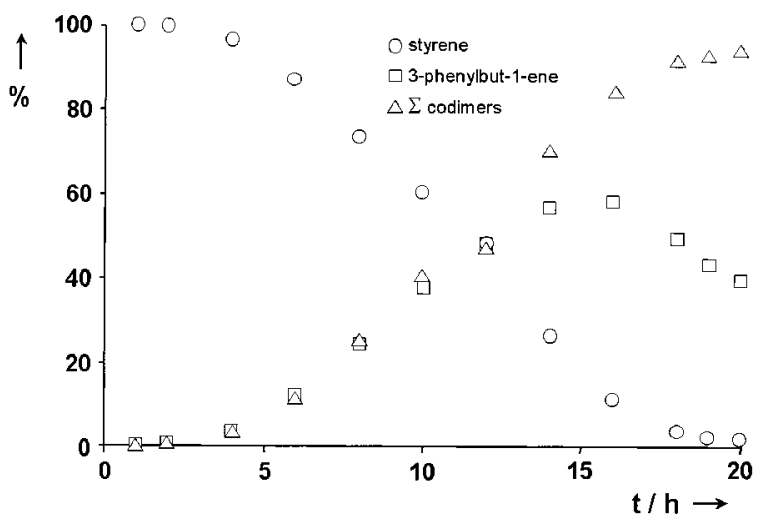

a Conditions: $\mathrm{T}=23{ }^{\circ} \mathrm{C}, 30$ bar initial pressure; $\mathrm{P} / \mathrm{Pd}=1$; styrene/Pd = 700; styrene ( $4 \mathrm{~mL}, 34.8 \mathrm{mmol}) ; 20 \mathrm{~mL}$ of $\mathrm{CH}_{2} \mathrm{Cl}_{2}$.

which can be ascribed to the formation of the active species, depends on the type of ligand used.

Since the induction periods in the batch reaction and in the continuous catalysis are of the same length, one can postulate that the catalytic complex undergoes the same activation steps in the membrane reactor as in the autoclave. This is confirmed by the results obtained when using a mononuclear phosphinite ligand. ${ }^{33}$

As a consequence of the results obtained with the $\mathrm{G}_{0}$ catalyst $\mathbf{9 b}$, some conditions were changed applying the $\mathrm{G}_{1}-\mathrm{Pd}_{12}$ catalyst $\mathbf{1 0 b}$ (see Figure 2). The catalytic complex was not synthesized starting from the [(methallyl)Pd(cod) $\mathrm{BF}_{4}$ precursor, but by reaction of the $[(\mathrm{allyl}) \mathrm{Pdl}]_{2}$ dimer with the phosphine ligand and subsequent $a b-$ straction of the iodide using silver hexafluoroantimonate. This procedure ensures the formation of the hemilabile, seven-membered $\mathrm{P} \wedge \mathrm{O}$-chelate ring. We assume that the precipitation of palladium black is connected with a double or multiple complexation of the phosphino groups to the palladium, which would lead to a lack of ligand in the catalytic solution. Using the presynthesized hemilabile chelate complex as the catalyst precursor, the necessity of the displacement of the cyclooctadiene is avoided. As a consequence, a positive influence on the length of the induction period was expected.

Additionally, the amount of catalyst used was increased by 2.5 times in case of a positive concentration effect on the induction period. Due to both the higher concentration and the higher expected retention of the $\mathrm{G}_{1}$ catalyst $\mathbf{1 0 b}$, the activity decrease caused by washout should only be of minor importance. Chart 3 shows the space-time yield obtained in the continuous catalysis in the presence of the $\mathrm{G}_{1}$ dendritic catalyst $\mathbf{1 0 b}$ as a function of time.

Despite the use of a different catalyst precursor and the higher retention of the $G_{1}$ dendritic catalyst, the time dependent product formation resembles al most perfectly the one found with the $\mathrm{G}_{0}$ catalyst. The induction periods are nearly identical. Therefore, this period cannot be due to the displacement of the cyclooctadiene but to the formation of the palladium hydride species. After $8 \mathrm{~h}$, the system achieves its maximum productivity of $7.5 \mathrm{~g}$ $\mathrm{L}^{-1} \mathrm{~h}^{-1}$, which is 3.2 times higher than in the continuous catalysis in the presence of the $\mathrm{G}_{0}$ ligand $\mathbf{9 b}$. This does not correspond completely to the increase in catalyst concentration, but it can be assumed that by use of the 


\section{Chart 3. Continuous Hydrovinylation of Styrene in a Membrane Reactor Using Dendrimer $\mathrm{G}_{1}-\left(\mathrm{OC}(\mathrm{O})\left(\mathrm{CH}_{2}\right)_{3} \mathrm{PPh}_{2}\right)_{12}{ }^{\mathrm{a}}$}

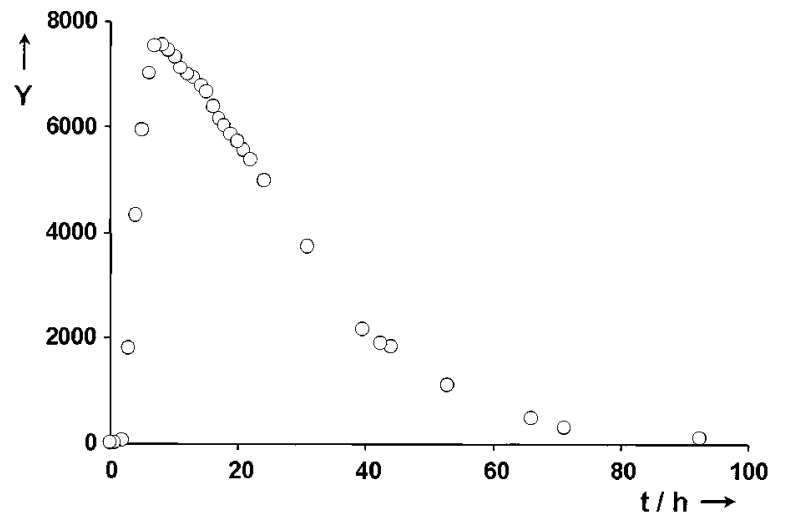

a Conditions: $\mathrm{T}=23^{\circ} \mathrm{C}, \mathrm{p}=30 \mathrm{bar}, 0.13 \mathrm{mmol} \mathrm{Pd}, \mathrm{L} / \mathrm{Pd}=1$, flow rates: ethylene solution $2.5 \mathrm{mLh}^{-1}(10 \mathrm{M})$, styrene solution $2.5 \mathrm{~mL} \mathrm{~h}^{-1}(1.8 \mathrm{M}), \tau=4 \mathrm{~h}, \mathrm{MPF}-60 \mathrm{NF}$ membrane (Koch Int., Düsseldorf, Ger.). Y) space time yield $\left(\mathrm{mg} \mathrm{L}^{-1} \mathrm{~h}^{-1}\right)$.

\section{Chart 4. Maximum Productivity of the Catalyst $\left[(\text { allyl }) \mathbf{P d}\left(\mathbf{G}_{1}\right)\right]^{+}$SbF $_{6}{ }^{- \text {a }}$}

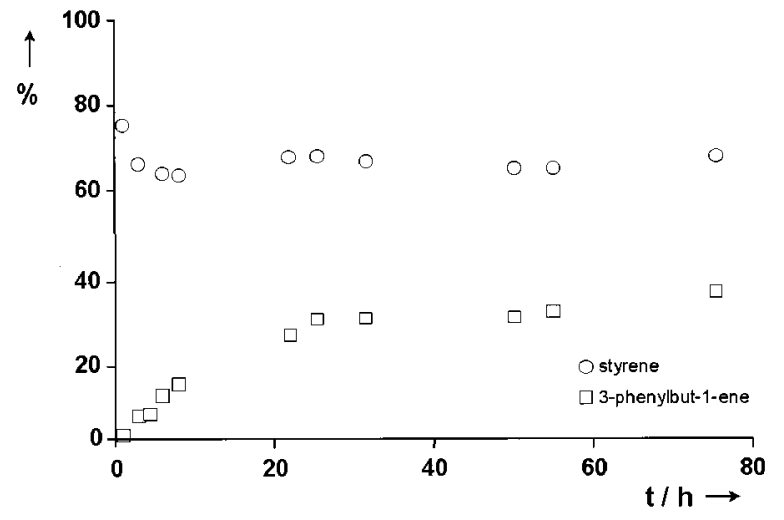

a Conditions: $\mathrm{T}=23{ }^{\circ} \mathrm{C}, \mathrm{p}=30 \mathrm{bar} ; \mathrm{P} / \mathrm{Pd}=1$; styrene/Pd $=$ 10.400; styrene ( $30 \mathrm{~mL}, 260 \mathrm{mmol}$ ); $20 \mathrm{~mL}$ of $\mathrm{CH}_{2} \mathrm{Cl}_{2}$.

[(allyl)Pdl $]_{2} / \mathrm{AgSbF}_{6}$ system more active hydride species are available. At the maximum, the chemoselectivity amounts to $80 \%$ which is significantly lower than in the catalysis using the $\mathrm{G}_{0}$ ligand $\mathbf{9 b}$. The sel ectivity drop can be ascribed to the different precursor system, as similar observations were made in corresponding batch reactions. The decrease of the activity in the continuous catalysis using the $\mathrm{G}_{1}$ dendritic ligand $\mathbf{1 0 b}$ is as rapid as with the $\mathrm{G}_{0}$ ligand $\mathbf{9 b}$. Therefore, after $80 \mathrm{~h}$ the product fraction in the solution is minimal. Due to the similarity of the results obtained with the $\mathrm{G}_{0}$ compound and the $\mathrm{G}_{1}$ dendrimer, the activity drop can only secondarily be connected to the washout. The drastic decrease must rather be ascribed to a catalyst deactivation, which is independent of the precursor and starts within the first $10 \mathrm{~h}$ of the catalysis.

A total turnover number of 260 is obtained in the continuous catalysis. The next step was the correlation of this value to the maximum efficiency of the system obtained in the batch reaction. For this reason, catalytic runs with a high catalyst loading (styrene/pal ladium = 10400 ) were conducted with both the $G_{1}$ dendritic ligand $\mathbf{1 0 b}$ and the mononuclear model compound $\mathbf{8 b}$. The courses of conversion and yield are given in Chart 4. The graph shows clearly that also these systems possess only a limited efficiency. Complete conversion is not achieved under these conditions. As in the continuous runs, within the first $10 \mathrm{~h}$ the catalyst reaches its maximum productivity. Afterward, the conversion falls off and after about $30 \mathrm{~h}$ no further conversion is obtained. With the $\mathrm{G}_{1}$ dendritic system a total turnover number of 3273 is obtained, whereas with the mononuclear compound the total turnover number comes to 6027. The dendritic system ther efore is even less stable than the mononudear compound. This is supposed to be due to the flexibility of the dendritic arms bringing the phosphino end groups close to each other. This facilitates the formation of diphosphine complexes leading to a deactivation of the catalyst followed by the precipitation of palladium black.

\section{Concluding Remarks}

In conclusion, the model complexes used have a limited efficiency resulting from a restricted lifetime. Despite the stabilization by the hemilabile coordination, within $10 \mathrm{~h}$ the dendritic catalyst complexes start to deactivate. This is indicated by the precipitation of palladium black in the reactor and on the membrane surface. The deactivation process must be ascribed to double or multiple phosphine complexation. The multiple coordination surely is facilitated by the low space-filling properties of the diphenyl phosphino groups. However, NMR investigations with the freshly prepared catalyst solutions suggest that independently of the precursor used, initially the pure monophosphine complex is formed. The deactivation process therefore occurs during the catalysis. Since the deactivation process takes a similar course but different turnovers are reached in the batch reaction as well as in the continuous catalysis, it can be excluded that it is correlated to the amount of converted styrene or solvent contacted.

\section{Experimental Section}

General Data. All reactions were carried out using standard Schlenk techniques under an inert atmosphere of dry, oxygen-free nitrogen unless otherwise stated. DMF was dried on molecular sieves ( $4 \AA$ ) prior to use, $\mathrm{Et}_{2} \mathrm{O}, \mathrm{THF}$, and hexane were carefully dried and distilled from $\mathrm{N}$ a/benzophenone prior to use, and $\mathrm{CH}_{2} \mathrm{Cl}_{2}$ was distilled from $\mathrm{CaH}_{2}$. The carbosilane functionalized compounds $\mathbf{4}$ and $\mathbf{5}$ were prepared according to a literature procedure. ${ }^{12}$ Styrene was purchased from Fluka and distilled from $\mathrm{CaH}_{2}$ under argon. The ethene used has a purity of $>99.5 \%$. $\left[\left(\eta^{3}-\mathrm{C}_{3} \mathrm{H}_{5}\right) \mathrm{Pdl}\right]_{2}$ was prepared by a literature procedure. ${ }^{40} \mathrm{All}$ other standard chemicals were purchased from ACROS Chimica or Aldrich Chemical Co. and used without further purification. Catalytic experiments under pressure were carried out in $75 \mathrm{~mL}$ stainless steel autoclaves equipped with a magnetic stirring bar. Mass spectra obtained under electron ionization (EI) conditions (70 eV) were recorded by linear scanning from $\mathrm{m} / \mathrm{z}$ 50-500. FAB-MS spectra were recorded either on a (1) J EOL J MS SX/SX 102A four-sector mass spectrometer, operated at $10 \mathrm{kV}$ accelerating voltage, equipped with a J EOL MS-FAB $10 \mathrm{D}$ FAB gun operated at a $5 \mathrm{~mA}$ emission current, producing a beam of $6 \mathrm{keV}$ xenon atoms or a (2) J EOL J MS AX 505 spectrometer, operated at 3 $\mathrm{kV}$ accelerating voltage, equipped with a J EOL MS-FAB 10 D FAB gun operated at a $10 \mathrm{~mA}$ emission current, producing a beam of $6 \mathrm{keV}$ xenon atoms. The spectra were obtained from the Analytical Chemical Department of the University of Utrecht. MALDI-TOF-MS spectra were acquired using a Voyager-DE BioSpectrometry Workstation (PerSeptive Bio-

(40) White, D. A. Inorg. Synth. 1972, 13, 55 
systems I nc., Framingham, MA) mass spectrometer equipped with nitrogen laser emitting at $337 \mathrm{~nm}$. The instrument was operated in the linear mode at an accelerating voltage in the range 23000-25000 V. External calibration was performed using insulin (bovine), and detection was done by means of a linear detector and a digitizing oscilloscope operating at 500 $\mathrm{MHz}$. Sample solutions with $(30 \mathrm{mg} / \mathrm{mL})$ in THF were used, and the matrix was 3,5-dihydroxybenzoic acid in THF (34 mg/ $\mathrm{mL}$ ). A solution of silver (I) trifluoroacetate in THF was added in order to improve the peak resolution. The sample solution $(0.2 \mathrm{~mL})$ and the matrix solution $(0.2 \mathrm{~mL})$ were combined and placed on a gold MALDI target and analyzed after evaporation of the solvents. Elemental microanalyses were obtained from Dornis und Kol be Mikroanalytisches Laboratorium, Mülheim a.d. Ruhr, Germany.

Synthesis of Phosphine Oxide Ligands. Diphenylphosphinoxy carboxylic acids were prepared following a literature procedure. ${ }^{39}$ These were then converted to the acid chlorides by treatment with a $0.5 \mathrm{M}$ solution of thionyl chloride in THF. The acid chlorides were not isolated but used directly after evaporation to dryness.

Diphenylphosphinoxy Propionic Benzyl Ester (3a). To a solution of 4-(dimethylamino)pyridine $(0.63 \mathrm{~g}, 5.16 \mathrm{mmol})$ in DMF (15 mL) was added a solution of diphenylphosphinoxy propionyl chloride $(1.50 \mathrm{~g}, 5.13 \mathrm{mmol})$ in DMF $(10 \mathrm{~mL})$ at room temperature. Subsequently, a solution of benzylic alcohol $(0.4$ $\mathrm{g}, 3.7 \mathrm{mmol})$ in DMF ( $10 \mathrm{~mL}$ ) was added to the orange solution. The mixture was stirred overnight and filtered. I ce-water was added, and the mixture was extracted with $\mathrm{Et}_{2} \mathrm{O}$. The combined organic layers were washed with water and dried over $\mathrm{Na}_{2} \mathrm{SO}_{4}$. The solvent was removed in vacuo, and after purification by column chromatography (silica/ $\mathrm{CH}_{2} \mathrm{Cl}_{2}$ ) colorless crystals were obtained. Yield: $1.27 \mathrm{~g}, 3.5 \mathrm{mmol}, 95 \%$. M : $96{ }^{\circ} \mathrm{C}$. ${ }^{1} \mathrm{H} \mathrm{NMR}\left(\mathrm{CDCl}_{3}, 298 \mathrm{~K}\right): \delta=7.74(\mathrm{~m}, 4 \mathrm{H}), 7.49(\mathrm{~m}, 6 \mathrm{H}), 7.32$ $(\mathrm{m}, 5 \mathrm{H}), 5.07(\mathrm{~s}, 2 \mathrm{H}), 2.65(\mathrm{~m}, 4 \mathrm{H}) \cdot{ }^{13} \mathrm{C}\left\{{ }^{1} \mathrm{H}\right\}-\mathrm{NMR}:\left(\mathrm{CDCl}_{3}, 298\right.$ $\mathrm{K}): \delta=172.1\left(\mathrm{~d}, 3_{\mathrm{CP}}=17.1,1 \mathrm{C}\right), 135.5(\mathrm{~s}, 1 \mathrm{C}), 132.1(\mathrm{~d}$, $\left.{ }^{1} \mathrm{~J}_{\mathrm{CP}}=99.8,2 \mathrm{C}\right), 131.9(\mathrm{~d}, 4 \mathrm{~J} \mathrm{CP}=2.8,2 \mathrm{C}), 130.7\left(\mathrm{~d}, \mathrm{~J}_{\mathrm{CP}}=9.4\right.$, 4C), $128.7(\mathrm{~d}, \mathrm{~J} \mathrm{CP}=11.6,4 \mathrm{C}), 128.5(\mathrm{~s}, 2 \mathrm{C}), 128.2(\mathrm{~s}, 1 \mathrm{C}), 128.1$ $(\mathrm{s}, 2 \mathrm{C}), 66.7(\mathrm{~s}, 1 \mathrm{C}), 26.4(\mathrm{~d}, 2 \mathrm{~J} \mathrm{CP}=1.8,1 \mathrm{C}), 25.0(\mathrm{~d}, 1 \mathrm{~J} \mathrm{CP}=$ 72.6, 1C). ${ }^{31} \mathrm{P}\left\{{ }^{1} \mathrm{H}\right\}-N M R:\left(\mathrm{CDCl}_{3} ; 298 \mathrm{~K}\right): \delta=31.9$ (s). GCMS: (rel intensity): m/z $364\left(<1 \%, M^{+} ; 257\right.$ (10), 230 (15), 202 (100), 183 (10), 155 (10), 91 (40). IR $\left(\mathrm{CHCl}_{3}\right): 1740 \mathrm{~cm}^{-1}(\mathrm{C}=\mathrm{O})$, $1179 \mathrm{~cm}^{-1}(\mathrm{P}=\mathrm{O})$. Anal. Calcd for $\mathrm{C}_{22} \mathrm{H}_{21} \mathrm{O}_{3} \mathrm{P}$ (mw: 364.38): C, 72.52; H, 5.81; P, 8.50. Found: C, 72.35; H, 5.83; P, 8.38.

Diphenylphosphinoxy Butyric Benzyl Ester (3b). The synthetic procedure was identical to that described for $\mathbf{3 a}$, starting from benzyl alcohol $(0.65 \mathrm{~g}, 6.0 \mathrm{mmol}), 4$-(dimethylamino)pyridine (1.46 g, $12.0 \mathrm{mmol}$ ) and diphenyl phosphinoxy butyric acid chloride $(2.75 \mathrm{~g}, 9.00 \mathrm{mmol})$. A slightly yellow oil was obtained. Yield: $1.28 \mathrm{~g}, 3.4 \mathrm{mmol}, 57 \% .{ }^{1} \mathrm{H}$ NMR $\left(\mathrm{CDCl}_{3}\right.$, $298 \mathrm{~K}): \delta=7.74(\mathrm{~m}, 4 \mathrm{H}$, ortho PArH $), 7.47(\mathrm{~m}, 6 \mathrm{H}), 7.32(\mathrm{~m}$, $5 \mathrm{H}), 5.08(\mathrm{~s}, 2 \mathrm{H}), 2.48(\mathrm{t}, \mathrm{J}=6.8,2 \mathrm{H}), 2.32(\mathrm{~m}, 2 \mathrm{H}), 1.97(\mathrm{~m}$, $2 \mathrm{H}) \cdot{ }^{13} \mathrm{C}\left\{{ }^{1} \mathrm{H}\right\}-\mathrm{NMR}:\left(\mathrm{CDCl}_{3}, 298 \mathrm{~K}\right): \delta=172.7(\mathrm{~s}, 1 \mathrm{C}), 136.1$ $(\mathrm{s}, 1 \mathrm{C}), 133.0(\mathrm{~d}, 1 \mathrm{~J} \mathrm{CP}=105.6,2 \mathrm{C}), 132.0(\mathrm{~d}, 4 \mathrm{~J} \mathrm{CP}=3,2 \mathrm{C})$, $131.0\left(\mathrm{~d}, J_{\mathrm{CP}}=9.2,4 \mathrm{C}\right), 128.9\left(\mathrm{~d}, \mathrm{~J}_{\mathrm{CP}}=11.1,4 \mathrm{C}\right), 128.8(\mathrm{~s}$, 2C), 128.5 (s, 1C), $128.5(\mathrm{~s}, 2 \mathrm{C}), 66.5(\mathrm{~s}, 1 \mathrm{C}), 34.9$ (d, 3 $\mathrm{sP}=$ 14.3, 1C), $29.2\left(d,{ }^{1} \mathrm{CP}=71.9,1 \mathrm{C}\right), 17.6\left(\mathrm{~d},{ }^{2} \mathrm{~J} \mathrm{CP}=3.7,1 \mathrm{C}\right)$. ${ }^{31} \mathrm{P}\left\{{ }^{1} \mathrm{H}\right\}-N M R: \quad\left(\mathrm{CDCl}_{3} ; 298 \mathrm{~K}\right): \delta=33.2$ (s). GC-MS: (rel intensity): $\mathrm{m} / \mathrm{z} 378$ (10), $\mathrm{M}^{+}$; 271 (20), 243 (40), 215 (100), 202 (70), 183 (10), 155 (10), 91 (70). IR (CHCl): $1745 \mathrm{~cm}^{-1}(\mathrm{C}=\mathrm{O})$, $1188 \mathrm{~cm}^{-1}(\mathrm{P}=\mathrm{O})$. Anal. Calcd for $\mathrm{C}_{23} \mathrm{H}_{23} \mathrm{O}_{3} \mathrm{P}$ (mw: 378.41 ): C, 73.00; H, 6.13; P, 8.19. Found: C, 73.18; H, 6.20; P, 8.06.

$\mathrm{G}_{0}-\left(\mathrm{OC}(\mathrm{O})\left(\mathrm{CH}_{2}\right)_{2} \mathrm{P}(\mathrm{O}) \mathrm{Ph}_{2}\right)_{4}, \mathrm{Si}\left\{\left(\mathrm{CH}_{2}\right)_{3} \mathrm{SiMe}_{2}\left(\mathrm{C}_{6} \mathrm{H}_{4} \mathrm{CH}_{2} \mathrm{OC}\right.\right.$ (O) $\left.\left(\mathrm{CH}_{2}\right)_{2} \mathbf{P}(\mathbf{O}) \mathbf{P h}_{2}\right\}_{4}(\mathbf{6 a})$. The synthetic procedure was identical to that described for 3 a, starting from diphenylphosphinoxy propionic acid chloride (5.18 g, $17.7 \mathrm{mmol})$, 4-(dimethylamino)pyridine ( $2.47 \mathrm{~g}, 20.2 \mathrm{mmol})$, and 4 ( $2.13 \mathrm{~g}, 2.48 \mathrm{mmol})$. A slightly yellow oil was obtained. Yield: $2.0 \mathrm{~g}, 1.1 \mathrm{mmol}, 43 \%$. ${ }^{1} \mathrm{H} \mathrm{NMR}\left(\mathrm{CDCl}_{3}, 298 \mathrm{~K}\right): \delta=7.69(\mathrm{~m}, 16 \mathrm{H}), 7.53-7.41(\mathrm{~m}$, $32 \mathrm{H}), 7.27-7.25(\mathrm{~d}, \mathrm{~J}=7.6,8 \mathrm{H}), 5.05(\mathrm{~s}, 8 \mathrm{H}), 2.65(\mathrm{~m}, 16 \mathrm{H})$ $1.27(\mathrm{~m}, 8 \mathrm{H}), 0.77(\mathrm{~m}, 8 \mathrm{H}), 0.54(\mathrm{~m}, 8 \mathrm{H}), 0.18(\mathrm{~s}, 24 \mathrm{H}) .{ }^{13} \mathrm{C}-$ $\left\{{ }^{1} \mathrm{H}\right\}-N M R:\left(\mathrm{CDCl}_{3}, 298 \mathrm{~K}\right): \delta=172.1\left(\mathrm{~d},{ }^{3} \mathrm{CP}=17.1,4 \mathrm{C}\right)$, $140.0(\mathrm{~s}, 4 \mathrm{C}), 135.8(\mathrm{~s}, 4 \mathrm{C}), 133.7(\mathrm{~s}, 8 \mathrm{C}), 132.1\left(\mathrm{~d},{ }^{1} \mathrm{~J} \mathrm{CP}=99.8\right.$, 8C), $131.9(\mathrm{~d}, 4 \mathrm{~J} \mathrm{CP}=2.8,8 \mathrm{C}), 130.7\left(\mathrm{~d}, \mathrm{~J}_{\mathrm{CP}}=9.4,16 \mathrm{C}\right), 128.7$ $\left(d, J_{C P}=11.9,16 C\right), 127.4(s, 8 C), 66.7(s, 4 C), 26.4(s, 4 C)$, $24.9\left(\mathrm{~d}, \mathrm{~J}_{\mathrm{CP}}=72.6,4 \mathrm{C}\right), 20.4(\mathrm{~s}, 4 \mathrm{C}), 18.4(\mathrm{~s}, 4 \mathrm{C}), 17.3(\mathrm{~s}, 4 \mathrm{C})$, -3.0 (s, 8C). ${ }^{31} \mathrm{P}\left\{{ }^{1} \mathrm{H}\right\}-\mathrm{NMR}:\left(\mathrm{CDCl}_{3} ; 298 \mathrm{~K}\right): \delta=32.1$ (s). FABMS: (rel intensity): m/z $1906\left(\mathrm{G}_{0}\left(\mathrm{CH}_{2}\right)_{2} \mathrm{P}(\mathrm{O}) \mathrm{Ph}_{2}+\mathrm{Na}\right)^{+}, 1883$ $\left(\mathrm{G}_{0}\left(\mathrm{CH}_{2}\right)_{2} \mathrm{P}(\mathrm{O}) \mathrm{Ph}_{2}+\mathrm{H}\right)^{+}$. IR $\left(\mathrm{CHCl}_{3}\right): 1732 \mathrm{~cm}^{-1}(\mathrm{C}=\mathrm{O}), 1179$ $\mathrm{cm}^{-1}(\mathrm{P}=\mathrm{O})$. Anal. Calcd for $\mathrm{C}_{108} \mathrm{H}_{128} \mathrm{O}_{12} \mathrm{P}_{4} \mathrm{Si}_{5}$ (mw: 1882.54): C, 68.91; H, 6.85; $P, 6.58 ; \mathrm{Si}, 7.46$. Found: $C, 68.78 ; \mathrm{H}, 6.88$; $\mathrm{P}, 6.66 ; \mathrm{Si}, 7.41$.

$\mathrm{G}_{0}-\left(\mathrm{OC}(\mathrm{O})\left(\mathrm{CH}_{2}\right)_{3} \mathrm{P}(\mathrm{O}) \mathrm{Ph}_{2}\right)_{2}, \mathrm{Si}\left\{\left(\mathrm{CH}_{2}\right)_{3} \mathrm{SiMe}_{2}\left(\mathrm{C}_{6} \mathrm{H}_{4} \mathrm{CH}_{2} \mathrm{OC}-\right.\right.$ (0) $\left.\left(\mathrm{CH}_{2}\right)_{3} \mathbf{P}(\mathbf{O}) \mathrm{Ph}_{2}\right\}_{4}(\mathbf{6 b})$. The synthetic procedure was identical to that described for 3a, starting from diphenylphosphinoxy butyric acid chloride $(2.30 \mathrm{~g}, 7.5 \mathrm{mmol}), 4$-(dimethylamino)pyridine (1.23 g, $10.0 \mathrm{mmol})$, and 4 (1.08 g, $1.26 \mathrm{mmol}$ ). A slightly yellow oil was obtained. Yield: $1.29 \mathrm{~g}, 0.67 \mathrm{mmol}$, $53 \% .{ }^{1} \mathrm{H}$ NMR $\left(\mathrm{CDCl}_{3}, 298 \mathrm{~K}\right): \delta=7.74(\mathrm{~m}, 16 \mathrm{H}), 7.53-7.43$ $(\mathrm{m}, 32 \mathrm{H}), 7.27(\mathrm{~d}, \mathrm{~J}=8.1,8 \mathrm{H}), 5.05(\mathrm{~s}, 8 \mathrm{H}), 2.49(\mathrm{t}, \mathrm{J}=7.0$, $8 \mathrm{H}), 2.31(\mathrm{~m}, 8 \mathrm{H}), 1.97(\mathrm{~m}, 8 \mathrm{H}) 1.29(\mathrm{~m}, 8 \mathrm{H}), 0.75(\mathrm{t}, \mathrm{J}=8.0$, $8 \mathrm{H}), 0.52(\mathrm{t}, 8 \mathrm{H}), 0.20(\mathrm{~s}, 24 \mathrm{H}) .{ }^{13} \mathrm{C}\left\{{ }^{1} \mathrm{H}\right\}-\mathrm{NMR}:\left(\mathrm{CDCl}_{3}, 298\right.$ K): $\delta=172.7(\mathrm{~s}, 4 \mathrm{C}), 140.2(\mathrm{~s}, 4 \mathrm{C}), 136.4(\mathrm{~s}, 4 \mathrm{C}), 134.0(\mathrm{~s}$, 8C), $133.0(\mathrm{~d}, 1 \mathrm{~J} \mathrm{CP}=100.6,8 \mathrm{C}), 131.9\left(\mathrm{~d}, \mathrm{U}_{\mathrm{CP}}=2.4,8 \mathrm{C}\right), 131.0$ $\left(d, J_{C P}=9.2,16 C\right), 128.9\left(d, J_{C P}=12.0,16 C\right), 127.7(s, 8 C)$, $66.5(\mathrm{~s}, 4 \mathrm{C}), 34.9(\mathrm{~d}, 3 \mathrm{~J} \mathrm{CP}=14.3,4 \mathrm{C}), 29.2\left(\mathrm{~d},{ }^{1} \mathrm{~J} \mathrm{CP}=71.8,4 \mathrm{C}\right)$, $20.7(\mathrm{~s}, 4 \mathrm{C}), 18.8(\mathrm{~s}, 4 \mathrm{C}), 17.6\left(\mathrm{~d},{ }^{2} \mathrm{~J} \mathrm{CP}=4.1,4 \mathrm{C}\right), 17.5(\mathrm{~s}, 4 \mathrm{C})$, $-2.6(\mathrm{~s}, 8 \mathrm{C}) .{ }^{31} \mathrm{P}\left\{{ }^{1} \mathrm{H}\right\}-\mathrm{NMR}:\left(\mathrm{CDCl}_{3} ; 298 \mathrm{~K}\right): \delta=33.1$ (s). FABMS: (rel intensity): $\mathrm{m} / \mathrm{z} 1961.0\left(\mathrm{G}_{0}\left(\mathrm{CH}_{2}\right)_{3} \mathrm{P}(\mathrm{O}) \mathrm{Ph}_{2}+\mathrm{Na}\right)^{+}$, $1939.0\left(\mathrm{G}_{0}\left(\mathrm{CH}_{2}\right)_{3} \mathrm{P}(\mathrm{O}) \mathrm{Ph}_{2}+\mathrm{H}\right)^{+}$. IR $\left(\mathrm{CHCl}_{3}\right): 1749 \mathrm{~cm}^{-1}(\mathrm{C}=$ O), $1171 \mathrm{~cm}^{-1}(\mathrm{P}=\mathrm{O})$. Anal. Calcd for $\mathrm{C}_{112} \mathrm{H}_{136} \mathrm{O}_{12} \mathrm{P}_{4} \mathrm{Si}_{5}$ (mw: 1938.64): C, 69.39; H, 7.07; Si, 7.24. Found: C, 69.19; H, 7.02; $\mathrm{Si}, 7.36$.

$\mathrm{G}_{1-}-\left(\mathrm{OC}(\mathrm{O})\left(\mathrm{CH}_{2}\right)_{2} \mathrm{P}(\mathrm{O}) \mathrm{Ph}_{2}\right)_{12}, \mathrm{Si}\left\{\left(\mathrm{CH}_{2}\right)_{3} \mathrm{Si}\left(\left(\mathrm{CH}_{2}\right)_{3} \mathrm{SiMe}_{2}\right.\right.$ $\left.\left(\mathrm{C}_{6} \mathrm{H}_{4} \mathrm{CH}_{2} \mathrm{OC}(\mathbf{O})\left(\mathrm{CH}_{2}\right)_{2}-\mathrm{P}(\mathbf{O}) \mathrm{Ph}_{2}\right)_{3}\right\}_{4}(7 \mathrm{a})$. The synthetic procedure was identical to that described for $3 \mathbf{3}$, starting from diphenylphosphinoxy propionic acid chloride (1.34 g, 4.58 $\mathrm{mmol}), 4-(d i$ methylamino)pyridine $(0.61 \mathrm{~g}, 5.00 \mathrm{mmol})$, and 5 $(0.71 \mathrm{~g}, 0.25 \mathrm{mmol})$. A slightly yellow oil was obtained. Yield: $1.27 \mathrm{~g}, 0.22 \mathrm{mmol}, 85 \%$. ${ }^{1} \mathrm{H}$ NMR $\left(\mathrm{CDCl}_{3}, 298 \mathrm{~K}\right): \delta=7.72$ $(\mathrm{m}, 48 \mathrm{H}), 7.59-7.31(\mathrm{~m}, 96 \mathrm{H}), 7.24(\mathrm{~d}, \mathrm{~J}=7.8,24 \mathrm{H}), 5.00(\mathrm{~s}$, $24 \mathrm{H}), 2.62(\mathrm{~m}, 48 \mathrm{H}), 1.29(\mathrm{~m}, 32 \mathrm{H}), 0.77(\mathrm{~m}, 24 \mathrm{H}), 0.54(\mathrm{~m}$, $40 \mathrm{H}), 0.17(\mathrm{~s}, 24 \mathrm{H}) \cdot{ }^{13} \mathrm{C}\left\{{ }^{1} \mathrm{H}\right\}-\mathrm{NMR}:\left(\mathrm{CDCl}_{3}, 298 \mathrm{~K}\right): \delta=172.3$ $\left(\mathrm{d}, 3 \mathrm{~J}_{\mathrm{CP}}=17.1,12 \mathrm{C}\right), 140.2(\mathrm{~s}, 12 \mathrm{C}), 136.2(\mathrm{~s}, 12 \mathrm{C}), 134.3(\mathrm{~s}$, 24C), $132.2\left(d,{ }^{1} \mathrm{CP}_{\mathrm{CP}}=101.3,24 \mathrm{C}\right), 132.2\left(\mathrm{~d}, \mathrm{~J}_{\mathrm{CP}}=2.7,24 \mathrm{C}\right)$, $131.0\left(d, J_{C P}=9.2,48 C\right), 129.0\left(d, J_{C P}=11.5,48 C\right), 127.7(\mathrm{~s}$, 24C), $66.9(\mathrm{~s}, 12 \mathrm{C}), 26.7(\mathrm{~s}, 12 \mathrm{C}), 25.2\left(\mathrm{~d},{ }^{1} \mathrm{~J} \mathrm{CP}=73.2,12 \mathrm{C}\right)$, 20.7 (s, 12C), 18.9 (s, 16C), $18.4(4 \mathrm{C}), 18.1(4 \mathrm{C}), 17.7(\mathrm{~s}, 12 \mathrm{C})$ -2.6 (s, 24C). ${ }^{31} \mathrm{P}\left\{{ }^{1} \mathrm{H}\right\}-\mathrm{NMR}:\left(\mathrm{CDCl}_{3} ; 298 \mathrm{~K}\right): \delta=32.8(\mathrm{~s})$. MALDI-TOF-MS: m/z 5974.1 $\left[\mathrm{G}_{1}\left(\mathrm{CH}_{2}\right)_{2} \mathrm{P}(\mathrm{O}) \mathrm{Ph}_{2}+\mathrm{Ag}\right]^{+}$(calcd 5974.2). IR $\left(\mathrm{CHCl}_{3}\right): 1738 \mathrm{~cm}^{-1}(\mathrm{C}=\mathrm{O}), 1175 \mathrm{~cm}^{-1}(\mathrm{P}=\mathrm{O})$. Anal. Calcd for $\mathrm{C}_{108} \mathrm{H}_{128} \mathrm{O}_{12} \mathrm{P}_{4} \mathrm{Si}_{5}$ (mw: 1882.54): C, 68.73; $\mathrm{H}, 7.00$; $\mathrm{P}, 6.33$; Si, 8.13. Found: C, 68.79; H, 6.99; P, 6.26; Si, 8.21.

$\mathbf{G}_{1}-\mathrm{OC}(\mathrm{O})\left(\mathrm{CH}_{2}\right)_{3} \mathrm{P}(\mathrm{O}) \mathrm{Ph}_{2}, \mathrm{Si}\left\{\left(\mathrm{CH}_{2}\right)_{3} \mathrm{Si}\left(\left(\mathrm{CH}_{2}\right)_{3} \mathrm{SiMe}_{2}\left(\mathrm{C}_{6} \mathrm{H}_{4}\right.\right.\right.$ $\left.\left.\mathbf{C H}_{2} \mathrm{OC}(\mathbf{O})\left(\mathrm{CH}_{2}\right)_{3}-\mathbf{P}(\mathbf{O}) \mathbf{P h}_{2}\right)_{3}\right\}_{4}(\mathbf{7 b})$. The synthetic procedure was identical to that described for $\mathbf{3 a}$, starting from diphenylphosphinoxy butyric acid chloride (1.27 g, $4.13 \mathrm{mmol})$, 4-(dimethylamino)pyridine $(0.61 \mathrm{~g}, 5.00 \mathrm{mmol})$, and $5(0.64 \mathrm{~g}$, $0.23 \mathrm{mmol})$. A slightly yell ow oil was obtained. Yield: $1.12 \mathrm{~g}$, $0.19 \mathrm{mmol}, 81 \%$. ${ }^{1} \mathrm{H}$ NMR $\left(\mathrm{CDCl}_{3}, 298 \mathrm{~K}\right): \delta=7.75(\mathrm{~m}, 48 \mathrm{H})$, 7.60-7.34 (m, 96H), $7.24(\mathrm{~d}, \mathrm{~J}=6.6,24 \mathrm{H}), 5.02(\mathrm{~s}, 24 \mathrm{H}), 2.42$ $(\mathrm{t}, \mathrm{J}=7.1,24 \mathrm{H}), 2.30(\mathrm{~m}, 8 \mathrm{H}), 1.97(\mathrm{~m}, 8 \mathrm{H}), 1.31(\mathrm{~m}, 32 \mathrm{H})$, $0.75(\mathrm{~m}, 24 \mathrm{H}), 0.54(\mathrm{~m}, 40 \mathrm{H}), 0.18(\mathrm{~s}, 24 \mathrm{H}) .{ }^{13} \mathrm{C}\left\{{ }^{1} \mathrm{H}\right\}-\mathrm{NMR}$ : $\left(\mathrm{CDCl}_{3}, 298 \mathrm{~K}\right): \delta=172.7(\mathrm{~s}, 12 \mathrm{C}), 140.1(\mathrm{~s}, 12 \mathrm{C}), 136.6(\mathrm{~s}$, 12C), $133.9(\mathrm{~s}, 24 \mathrm{C}), 133.0(\mathrm{~d}, 1 \mathrm{~J} \mathrm{CP}=97.6,24 \mathrm{C}), 132.0(\mathrm{~d}$, $\left.{ }^{4} \mathrm{~J}_{C P}=2.8,24 \mathrm{C}\right), 131.0\left(\mathrm{~d}, \mathrm{~J}_{\mathrm{CP}}=9.2,48 \mathrm{C}\right), 128.9\left(\mathrm{~d}, \mathrm{~J}_{\mathrm{CP}}=11.5\right.$, 48C), $127.7(\mathrm{~s}, 24 \mathrm{C}), 66.4(\mathrm{~s}, 12 \mathrm{C}), 34.8\left(\mathrm{~d},{ }^{2} \mathrm{~J} \mathrm{cP}=14.3,12 \mathrm{C}\right)$, $29.2\left(\mathrm{~d},{ }^{1} \mathrm{~J} \mathrm{CP}=71.9,12 \mathrm{C}\right), 20.8(\mathrm{~s}, 12 \mathrm{C}), 18.9(\mathrm{~s}, 16 \mathrm{C}), 18.5(\mathrm{~s}$, 4C), $18.1(\mathrm{~s}, 4 \mathrm{C}), 17.7(\mathrm{~s}, 12 \mathrm{C}), 17.6\left(\mathrm{~d},{ }^{2} \mathrm{~J} \mathrm{CP}=3.3,12 \mathrm{C}\right),-2.5$ (s, 24C). ${ }^{31} \mathrm{P}\left\{{ }^{1} \mathrm{H}\right\}-\mathrm{NMR}:\left(\mathrm{CDCl}_{3} ; 298 \mathrm{~K}\right): \delta=32.9$ (s). MALDITOF-MS: $\mathrm{m} / \mathrm{z}$ 6142.6 $\left[\mathrm{G}_{1}\left(\mathrm{CH}_{2}\right)_{3} \mathrm{P}(\mathrm{O}) \mathrm{Ph}_{2}+\mathrm{Ag}\right]^{+}$(calcd 6142.4). IR $\left(\mathrm{CHCl}_{3}\right): 1754 \mathrm{~cm}^{-1}(\mathrm{C}=0), 1186 \mathrm{~cm}^{-1}(\mathrm{P}=\mathrm{O})$. Anal. Calcd for $\mathrm{C}_{112} \mathrm{H}_{136} \mathrm{O}_{12} \mathrm{P}_{4} \mathrm{Si}_{5}$ (mw: 1938.64): C, 69.19; $\mathrm{H}, 7.20 ; \mathrm{P}, 6.15$. Found: C, 69.25; H, 7.16; P, 6.06.

Synthesis of the Phosphine Ligands. Diphenylphosphino Propionic Benzyl Ester (8a). To a solution of 3a (0.89 g, $2.44 \mathrm{mmol})$ in $\mathrm{C}_{6} \mathrm{H}_{6}(20 \mathrm{~mL})$ were added degassed triethylamine $(0.7 \mathrm{~mL}, 5.1 \mathrm{mmol})$ and trichlorosilane $(2.3 \mathrm{~mL}, 23$ 
mmol). The mixture was heated under reflux overnight and the solvent removed in vacuo. After addition of $\mathrm{Et}_{2} \mathrm{O}(50 \mathrm{~mL})$, a yellow suspension was obtained which was filtered under a nitrogen atmosphere. The filtrate was diluted with degassed water and extracted with $\mathrm{Et}_{2} \mathrm{O}$. The combined organic layers were dried over $\mathrm{Na}_{2} \mathrm{SO}_{4}$ and concentrated in vacuo to yield a pale yellow oil $(0.5 \mathrm{~g}, 1.4 \mathrm{mmol}, 60 \%)$. ${ }^{1} \mathrm{H}$ NMR $\left(\mathrm{C}_{6} \mathrm{D}_{6}, 298 \mathrm{~K}\right)$ : $\delta=7.31(\mathrm{~m}, 4 \mathrm{H}), 7.15(\mathrm{~m}, 11 \mathrm{H}), 4.99(\mathrm{~s}, 2 \mathrm{H}), 2.31(\mathrm{~m}, 4 \mathrm{H})$. ${ }^{13} \mathrm{C}\left\{{ }^{1} \mathrm{H}\right\}-N M R:\left(\mathrm{C}_{6} \mathrm{D}_{6}, 298 \mathrm{~K}\right): \delta=172.7\left(\mathrm{~d},{ }^{3} \mathrm{CP}=15.0,1 \mathrm{C}\right)$, $139.2(\mathrm{~s}, 1 \mathrm{C}), 137.9\left(\mathrm{~d},{ }^{1} \mathrm{~J} \mathrm{CP}=95.9,2 \mathrm{C}\right), 133.4\left(\mathrm{~d},{ }^{4} \mathrm{~J}_{\mathrm{CP}}=18.8\right.$, 2C), 129.2 (s, 4C), 129.0 (d, J $\mathrm{CP}=7.3,4 \mathrm{C}$ ), 129.0 (s, 2C), 128.8 $(\mathrm{s}, 1 \mathrm{C}), 128.6(\mathrm{~s}, 2 \mathrm{C}), 66.8(\mathrm{~s}, 1 \mathrm{C}), 31.4\left(\mathrm{~d}, \mathrm{2}_{\mathrm{CP}}=20.0,1 \mathrm{C}\right)$, $23.9\left(\mathrm{~d},{ }^{1} \mathrm{CP}=13.1,1 \mathrm{C}\right) .{ }^{31} \mathrm{P}\left\{{ }^{1} \mathrm{H}\right\}-\mathrm{NMR}:\left(\mathrm{CDCl}_{3} ; 298 \mathrm{~K}\right): \delta=$ -15.1 (s). IR $\left(\mathrm{CHCl}_{3}\right)$ : $1732 \mathrm{~cm}^{-1}(\mathrm{C}=\mathrm{O})$. Anal. Calcd for $\mathrm{C}_{22} \mathrm{H}_{21} \mathrm{O}_{2} \mathrm{P}$ (mw: 348.38): C, 75.85; $\mathrm{H}, 6.08 ; \mathrm{P}, 8.89$. Found: C, 75.72; H, 6.00; P, 8.66.

Diphenylphosphino Butyric Benzyl Ester (8b). The synthetic procedure was identical to that described for $\mathbf{8 a}$, starting from $\mathbf{3 b}(0.81 \mathrm{~g}, 2.14 \mathrm{mmol})$, degassed triethylamine $(0.6 \mathrm{~mL}, 4.3 \mathrm{mmol})$, and trichlorosilane $(2.2 \mathrm{~mL}, 21.4 \mathrm{mmol})$. A slightly yellow oil was obtained. Yield: $0.58 \mathrm{~g}, 1.6 \mathrm{mmol}$, $60 \% .{ }^{1} \mathrm{H}$ NMR $\left(\mathrm{CDCl}_{3}, 298 \mathrm{~K}\right): \delta=7.59-7.30(\mathrm{~m}, 15 \mathrm{H}), 5.17$ $(\mathrm{s}, 2 \mathrm{H}), 2.55(\mathrm{t}, \mathrm{J}=7.0,2 \mathrm{H}), 2.15(\mathrm{~m}, 2 \mathrm{H}), 1.88(\mathrm{~m}, 2 \mathrm{H})$. ${ }^{13} \mathrm{C}\left\{{ }^{1} \mathrm{H}\right\}-N M R:\left(\mathrm{CDCl}_{3}, 298 \mathrm{~K}\right): \delta=173.1(\mathrm{~s}, 1 \mathrm{C}), 138.7(\mathrm{~d}$, $\left.{ }^{1} \mathrm{CP}_{\mathrm{CP}}=12.9,2 \mathrm{C}\right), 136.3(\mathrm{~s}, 1 \mathrm{C}), 133.0(\mathrm{~d}, \mathrm{~J} \mathrm{CP}=18.4,4 \mathrm{C}), 128.8$ $(\mathrm{m}, 6 \mathrm{C}), 128.8(\mathrm{~s}, 2 \mathrm{C}), 128.7(\mathrm{~s}, 1 \mathrm{C}), 128.5(\mathrm{~s}, 2 \mathrm{C}), 66.5(\mathrm{~s}, 1 \mathrm{C})$, $\left.35.7(d, 3)_{C P}=13.4,1 C\right), 27.8\left(d,{ }^{1} \mathrm{CP}=12.0,1 \mathrm{C}\right), 21.9(\mathrm{~d}$, $\left.{ }^{2} \mathrm{~J} C P=18.4,1 C\right) .{ }^{31} \mathrm{P}\left\{{ }^{1} \mathrm{H}\right\}-N M R:\left(\mathrm{CDCl}_{3} ; 298 \mathrm{~K}\right): \delta=-15.8$ (s). IR $\left(\mathrm{CHCl}_{3}\right)$ : $1732 \mathrm{~cm}^{-1},(\mathrm{C}=\mathrm{O})$. Anal. Calcd for $\mathrm{C}_{23} \mathrm{H}_{23} \mathrm{O}_{2} \mathrm{P}$ (mw: 362.41): C, 76.23; H, 6.40; P, 8.55. Found: $\mathrm{C}, 76.09 ; \mathrm{H}$, $6.54 ; \mathrm{P}, 8.39$.

$\mathrm{G}_{0}-\left(\mathrm{OC}(\mathrm{O})\left(\mathrm{CH}_{2}\right)_{2} \mathrm{PPh}_{2}\right)_{4}, \mathrm{Si}\left\{\left(\mathrm{CH}_{2}\right)_{3} \mathrm{SiMe}_{2}\left(\mathrm{C}_{6} \mathrm{H}_{4} \mathrm{CH}_{2} \mathrm{OC}-\right.\right.$ (0) $\left.\left(\mathbf{C H}_{2}\right)_{2} \mathbf{P P h}_{2}\right\}_{4}(\mathbf{9 a})$. The synthetic procedure was identical to that described for $\mathbf{8 a}$, starting from $\mathbf{6 a}(0.67 \mathrm{~g}, 0.36 \mathrm{mmol})$, degassed triethylamine $(0.40 \mathrm{~mL}, 2.9 \mathrm{mmol})$, and trichlorosilane $(0.7 \mathrm{~mL}, 7.0 \mathrm{mmol})$. A colorless oil was obtained. Yield: $0.34 \mathrm{~g}, 0.19 \mathrm{mmol}, 52 \%$. ${ }^{1} \mathrm{H}$ NMR $\left(\mathrm{C}_{6} \mathrm{D}_{6}, 298 \mathrm{~K}\right): \delta=7.46(\mathrm{~d}$, $\mathrm{J}=8.1,8 \mathrm{H}), 7.33(\mathrm{~m}, 16 \mathrm{H}), 7.27(\mathrm{~d}, \mathrm{~J}=7.8,8 \mathrm{H}), 7.03(\mathrm{~m}$, $24 \mathrm{H}), 5.00(\mathrm{~s}, 8 \mathrm{H}), 2.34(\mathrm{~m}, 16 \mathrm{H}), 1.47(\mathrm{~m}, 8 \mathrm{H}), 0.85(\mathrm{~m}, 8 \mathrm{H})$, $0.63(\mathrm{t}, \mathrm{J}=8.3,8 \mathrm{H}), 0.26(\mathrm{~s}, 24 \mathrm{H}) .{ }^{13} \mathrm{C}\left\{{ }^{1} \mathrm{H}\right\}-\mathrm{NMR}:\left(\mathrm{C}_{6} \mathrm{D}_{6}, 298\right.$ $\mathrm{K}): \delta=172.8\left(\mathrm{~d}, 3_{\mathrm{CP}}=14.6,4 \mathrm{C}\right), 140.0(\mathrm{~s}, 4 \mathrm{C}), 139.1(\mathrm{~d}$, $\left.{ }^{1} \mathrm{CP}_{\mathrm{CP}}=14.0,8 \mathrm{C}\right), 137.7(\mathrm{~s}, 4 \mathrm{C}), 134.4(\mathrm{~s}, 8 \mathrm{C}), 133.4(\mathrm{~d}, 4 \mathrm{~J} \mathrm{CP}=$ 18.9, 8C), 129.2 (s, 8C), $129.1(\mathrm{~m}, 32 \mathrm{C}), 66.7(\mathrm{~s}, 4 \mathrm{C}), 31.4(\mathrm{~d}$, 2J $\mathrm{CP}=20.1,4 \mathrm{C}), 23.8(\mathrm{~d}, 1 \mathrm{c} \mathrm{CP}=13.1,4 \mathrm{C}), 21.2(\mathrm{~s}, 4 \mathrm{C}), 19.5$ $(\mathrm{s}, 4 \mathrm{C}), 18.2(\mathrm{~s}, 4 \mathrm{C}),-2.4(\mathrm{~s}, 8 \mathrm{C}) .{ }^{31} \mathrm{P}\left\{{ }^{1} \mathrm{H}\right\}-\mathrm{NMR}:\left(\mathrm{C}_{6} \mathrm{D}_{6} ; 298\right.$ K): $\delta=-17.3$ (s). FAB-MS: (rel intensity): $\mathrm{m} / \mathrm{z} 1850(\mathrm{M}+$ $2 \mathrm{O})^{+}, 1834(\mathrm{M}+\mathrm{O})^{+}, 1819(\mathrm{M}+\mathrm{H})^{+} . \mathrm{IR}\left(\mathrm{CHCl}_{3}\right): 1730 \mathrm{~cm}^{-1}$ $(\mathrm{C}=\mathrm{O})$.

$\mathrm{G}_{0}-\left(\mathrm{OC}(\mathrm{O})\left(\mathrm{CH}_{2}\right)_{3} \mathrm{PPh}_{2}\right)_{4}, \mathrm{Si}\left\{\left(\mathrm{CH}_{2}\right)_{3} \mathrm{SiMe}_{2}\left(\mathrm{C}_{6} \mathrm{H}_{4} \mathrm{CH}_{2} \mathrm{OC}-\right.\right.$ (O) $\left.\left(\mathbf{C H}_{2}\right)_{3} \mathbf{P P h}_{2}\right\}_{4}(\mathbf{9 b})$. The synthetic procedure was identical to that described for $\mathbf{8 a}$, starting from $\mathbf{6 b}(0.61 \mathrm{~g}, 0.31 \mathrm{mmol})$, degassed triethylamine $(0.40 \mathrm{~mL}, 2.9 \mathrm{mmol})$, and trichlorosilane $(0.65 \mathrm{~mL}, 6.5 \mathrm{mmol})$. A colorless oil was obtained. Yield: $0.36 \mathrm{~g}, 0.19 \mathrm{mmol}, 62 \%$. ${ }^{1} \mathrm{H}$ NMR $\left(\mathrm{CDCl}_{3}, 298 \mathrm{~K}\right): \delta=7.61-$ $7.23(\mathrm{~m}, 56 \mathrm{H}), 5.07(\mathrm{~s}, 8 \mathrm{H}), 2.47(\mathrm{t}, \mathrm{J}=7.4,8 \mathrm{H}), 2.11(\mathrm{~m}, 8 \mathrm{H})$, $1.80(\mathrm{~m}, 8 \mathrm{H}) 1.26(\mathrm{~m}, 8 \mathrm{H}), 0.80(\mathrm{t}, \mathrm{J}=7.8,8 \mathrm{H}), 0.52(\mathrm{t}, \mathrm{J}=$ 8.2, 8H), $0.21(\mathrm{~s}, 24 \mathrm{H}) .{ }^{13} \mathrm{C}\left\{{ }^{1} \mathrm{H}\right\}-N M R:\left(\mathrm{CDCl}_{3}, 298 \mathrm{~K}\right): \delta=$ $173.1(\mathrm{~s}, 4 \mathrm{C}), 140.1(\mathrm{~s}, 4 \mathrm{C}), 138.6$ (d, $\left.{ }^{1} \mathrm{cP}=12.4,8 \mathrm{C}\right), 136.6(\mathrm{~s}$, 4C), $134.0(\mathrm{~s}, 8 \mathrm{C}), 132.9(\mathrm{~d}, 4 \mathrm{~J} \mathrm{CP}=18.4,8 \mathrm{C}), 128.7(\mathrm{~m}, 32 \mathrm{C})$, 127.7 (s, 8C), $66.4(\mathrm{~s}, 4 \mathrm{C}), 35.6(\mathrm{~d}, 3 \mathrm{~J} \mathrm{CP}=13.3,4 \mathrm{C}), 27.8(\mathrm{~d}$, $\left.{ }^{1} \mathrm{~J} C P=12.0,4 C\right), 21.8\left(d,{ }^{2} \mathrm{CP}_{\mathrm{C}}=18.4,4 \mathrm{C}\right), 20.8(\mathrm{~s}, 4 \mathrm{C}), 18.8(\mathrm{~s}$, 4C), 17.7 (s, 4C), -2.6 (s, 8C). ${ }^{31} \mathrm{P}\left\{{ }^{1} \mathrm{H}\right\}-N M R:\left(\mathrm{CDCl}_{3} ; 298 \mathrm{~K}\right)$ : $\delta=-15.9$ (s). FAB-MS: (rel intensity): $\mathrm{m} / \mathrm{z} 1888.7(\mathrm{M}+\mathrm{O})^{+}$. IR $\left(\mathrm{CHCl}_{3}\right)$ : $1725 \mathrm{~cm}^{-1}(\mathrm{C}=\mathrm{O})$. Anal. Calcd for $\mathrm{C}_{112} \mathrm{H}_{136} \mathrm{O}_{8} \mathrm{P}_{4-}$ $\mathrm{Si}_{5}$ (mw: 1874.65): C, 71.76; H, 7.31; P, 6.61, Si, 7.49. F ound: C, 71.84; H, 7.38; P, 6.49, Si, 7.38.

$\mathbf{G}_{1}-\left(\mathrm{OC}(\mathrm{O})\left(\mathrm{CH}_{2}\right)_{2} \mathrm{PPh}_{2}\right)_{12}, \mathrm{Si}\left\{\left(\mathrm{CH}_{2}\right)_{3} \mathrm{Si}\left(\left(\mathrm{CH}_{2}\right)_{3} \mathrm{SiMe}_{2}\left(\mathrm{C}_{6}-\right.\right.\right.$ $\left.\left.\mathrm{H}_{4} \mathrm{CH}_{2} \mathrm{OC}(\mathrm{O})\left(\mathrm{CH}_{2}\right)_{2} \mathrm{PPh}_{2}\right)_{3}\right\}_{4}(\mathbf{1 0 a})$. The synthetic procedure was identical to that described for $\mathbf{8 a}$, starting from $7 \mathbf{a}(0.22$ $\left.\mathrm{g}, 3.75 \times 10^{-5} \mathrm{~mol}\right)$, degassed triethylamine $(0.13 \mathrm{~mL}, 9.4 \times$ $\left.10^{-4} \mathrm{~mol}\right)$, and trichlorosilane $(0.45 \mathrm{~mL}, 4.5 \mathrm{mmol})$. A colorless oil was obtained. Yield: $0.17 \mathrm{~g}, 0.030 \mathrm{mmol}, 80 \%$. ${ }^{1} \mathrm{H}$ NMR $\left(\mathrm{CDCl}_{3}, 298 \mathrm{~K}\right): \delta=7.61-7.20(\mathrm{~m}, 168 \mathrm{H}), 5.00(\mathrm{~s}, 24 \mathrm{H}), 2.46$ $(\mathrm{m}, 48 \mathrm{H}), 1.25(\mathrm{~m}, 32 \mathrm{H}), 0.75(\mathrm{~m}, 24 \mathrm{H}), 0.53(\mathrm{~m}, 40 \mathrm{H}), 0.17(\mathrm{~s}$,
24H). ${ }^{13} \mathrm{C}\left\{{ }^{1} \mathrm{H}\right\}-N M R:\left(\mathrm{CDCl}_{3}, 298 \mathrm{~K}\right): \delta=173.1\left(\mathrm{~d},{ }^{3} \mathrm{CP}=14.7\right.$, 4C), 140.1 (s, 12C), $138.0\left(\mathrm{~d}, \mathrm{l}_{\mathrm{CP}}=12.4,24 \mathrm{C}\right), 136.5(\mathrm{~s}, 12 \mathrm{C})$, $133.9(\mathrm{~s}, 24 \mathrm{C}), 132.7(\mathrm{~d}, \mathrm{~J} \mathrm{CP}=18.9,24 \mathrm{C}), 127.7(\mathrm{~s}, 24 \mathrm{C}), 128.7$ $(\mathrm{m}, 96 \mathrm{C}), 66.7(\mathrm{~s}, 12 \mathrm{C}), 31.0\left(\mathrm{~d},{ }^{2} \mathrm{~J} \mathrm{CP}=19.4,4 \mathrm{C}\right), 23.2(\mathrm{~d}$, 1] $\mathrm{CP}=12.0,4 \mathrm{C}), 20.8(\mathrm{~s}, 12 \mathrm{C}), 18.9(\mathrm{~s}, 16 \mathrm{C}), 18.5(\mathrm{~s}, 4 \mathrm{C}), 18.1$ $(\mathrm{s}, 4 \mathrm{C}), 17.7$ (s, 12C), $-2.5(\mathrm{~s}, 24 \mathrm{C}) .{ }^{31} \mathrm{P}\left\{{ }^{1} \mathrm{H}\right\}-\mathrm{NMR}:\left(\mathrm{CDCl}_{3}\right.$; $298 \mathrm{~K}): \delta=-14.8(\mathrm{~s})$. IR $\left(\mathrm{CHCl}_{3}\right): 1730 \mathrm{~cm}^{-1}(\mathrm{C}=\mathrm{O})$.

$\mathrm{G}_{1}-\left(\mathrm{OC}(\mathrm{O})\left(\mathrm{CH}_{2}\right)_{3} \mathrm{PPh}_{2}\right)_{4}, \mathrm{Si}\left\{\left(\mathrm{CH}_{2}\right)_{3} \mathrm{Si}\left(\left(\mathrm{CH}_{2}\right)_{3} \mathrm{SiMe}_{2}\left(\mathrm{C}_{6} \mathrm{H}_{4^{-}}\right.\right.\right.$ $\left.\left.\mathrm{CH}_{2} \mathrm{OC}(\mathbf{O})\left(\mathrm{CH}_{2}\right)_{3} \mathrm{PPh}_{2}\right)_{3}\right\}_{4}$ (10b). The synthetic procedure was identical to that described for $\mathbf{8 a}$, starting from $\mathbf{7 b}(0.13$ g, $\left.2.15 \times 10^{-5} \mathrm{~mol}\right)$, degassed triethylamine $(0.1 \mathrm{~mL}, 7.22 \times$ $\left.10^{-4} \mathrm{~mol}\right)$, and trichlorosilane $(0.26 \mathrm{~mL}, 2.58 \mathrm{mmol})$. A colorless oil was obtained. Yield: $0.10 \mathrm{~g}, 1.7 \times 10^{-5} \mathrm{~mol}, 80 \%$. ${ }^{1} \mathrm{H}$ NMR $\left(\mathrm{CDCl}_{3}, 298 \mathrm{~K}\right): \delta=7.58-7.16(\mathrm{~m}, 168 \mathrm{H}), 5.04(\mathrm{~s}, 24 \mathrm{H}), 2.45$ $(\mathrm{t}, \mathrm{J}=7.0,24 \mathrm{H}), 2.04(\mathrm{~m}, 24 \mathrm{H}), 1.76(\mathrm{~m}, 24 \mathrm{H}) 1.31(\mathrm{~m}, 32 \mathrm{H})$, $0.77(\mathrm{~m}, 24 \mathrm{H}), 0.55(\mathrm{~m}, 40 \mathrm{H}), 0.19(\mathrm{~s}, 24 \mathrm{H}) .{ }^{13} \mathrm{C}\left\{{ }^{1} \mathrm{H}\right\}-\mathrm{NMR}$ : $\left(\mathrm{CDCl}_{3}, 298 \mathrm{~K}\right): \delta=173.1(\mathrm{~s}, 12 \mathrm{C}), 140.0(\mathrm{~s}, 12 \mathrm{C}), 138.5(\mathrm{~d}$, 1J $C P=12.4,24 C), 136.7(\mathrm{~s}, 12 \mathrm{C}), 133.9(\mathrm{~s}, 24 \mathrm{C}), 132.9(\mathrm{~d}$, 4) $\mathrm{CP}=18.9,24 \mathrm{C}), 128.7(\mathrm{~m}, 96 \mathrm{C}), 127.7(\mathrm{~s}, 8 \mathrm{C}), 66.3(\mathrm{~s}, 12 \mathrm{C})$, $35.5(\mathrm{~d}, 3 \mathrm{~J} \mathrm{CP}=13.4,12 \mathrm{C}), 27.8(\mathrm{~d}, 1 \mathrm{~J} \mathrm{CP}=12.0,12 \mathrm{C}), 21.8(\mathrm{~d}$ 2) $\mathrm{CP}=18.4,12 \mathrm{C}), 20.8(\mathrm{~s}, 12 \mathrm{C}), 18.9(\mathrm{~s}, 16 \mathrm{C}), 18.5(4 \mathrm{C}), 18.1$ (4C), $17.7(\mathrm{~s}, 12 \mathrm{C}),-2.5(\mathrm{~s}, 24 \mathrm{C}) .{ }^{31} \mathrm{P}\left\{{ }^{1} \mathrm{H}\right\}-\mathrm{NMR}:\left(\mathrm{CDCl}_{3} ; 298\right.$ $\mathrm{K}): \delta=-15.7(\mathrm{~s})$. IR $\left(\mathrm{CHCl}_{3}\right): 1725 \mathrm{~cm}^{-1}(\mathrm{C}=\mathrm{O})$.

Preparation of the Cationic [(methallyl)PdP] $]^{+} \mathbf{B F}_{\mathbf{4}}$ Complexes. A solution of 1.00 equiv of the phosphorus $\mathrm{P} \wedge \mathrm{O}$ ligand $(0.05 \mathrm{mmol})$ in $\mathrm{CH}_{2} \mathrm{Cl}_{2}$ was added to a solution of 0.05 mmol of $\left[\left(\eta^{3}-\mathrm{C}_{4} \mathrm{H}_{7}\right) \mathrm{Pd}(\mathrm{cod})\right] \mathrm{BF}_{4}{ }^{[13]}$ in $\mathrm{CH}_{2} \mathrm{Cl}_{2}$. After stirring for $60 \mathrm{~min}$ at $0^{\circ} \mathrm{C}$, the resulting solution was used for catalysis.

Preparation of the Cationic $\left[\left(\mathbf{G}_{1}-\mathbf{P}_{12}\right)\{(\text { allyl }) \mathbf{P d}\}_{12}\right]^{12+}$ $\left(\mathrm{SbF}_{6}{ }^{-}\right)_{12}$ Complex for the Continuous Process. A solution of 1.00 equiv of the phosphorus $\mathrm{P} \wedge \mathrm{O}$ ligand $(0.011 \mathrm{mmol})$ in $\mathrm{CH}_{2} \mathrm{Cl}_{2}$ was added to a solution of $0.065 \mathrm{mmol}$ of $\left[\left(\eta^{3}-\mathrm{C}_{3} \mathrm{H}_{5}\right)-\right.$ $\mathrm{Pdl}]_{2}$ in $5 \mathrm{~mL}$ of $\mathrm{CH}_{2} \mathrm{Cl}_{2}$. After stirring for $30 \mathrm{~min}$ the sol ution was transferred to a flask containing 1.03 equiv of $\mathrm{AgSbF}_{6}$ in $2 \mathrm{~mL}$ of $\mathrm{CH}_{2} \mathrm{Cl}_{2}$. Subsequently, the mixture was stirred for 5 min and filtered over Celite. The solvents were removed in vacuo, $2 \mathrm{~mL}$ of $\mathrm{CH}_{2} \mathrm{Cl}_{2}$ was added, and the mixture was injected in the membrane reactor.

\section{Hydrovinylation Reaction}

Batch Reaction. The cold catalyst solution $(0.05 \mathrm{mmol}$ of $\left[\left(\eta^{3}-\mathrm{C}_{4} \mathrm{H}_{7}\right) \mathrm{Pd}(\mathrm{P} \wedge \mathrm{O})\right] \mathrm{BF}_{4}$ in $20 \mathrm{~mL}$ of $\left.\mathrm{CH}_{2} \mathrm{Cl}_{2}\right)$ was transferred into a $75 \mathrm{~mL}$ stainless steel autoclave via a syringe with a stainless steel needle. The autoclave was cooled in an ice bath. Chilled styrene $(4 \mathrm{~mL}$ : $34.8 \mathrm{mmol})$ was added, and the autoclave was pressurized with ethene (30 bar initial pressure). After the reaction, the autoclave was slowly vented, and the reaction mixture separated from the catalyst and higher ol igomers by flash chromatography over basic alumina. Products were analyzed by GC.

Continuous Catalysis. The membrane (MPF-60 NF membrane, Koch Int., Düsseldorf, Germany), stored in ethanol, was rinsed with acetone and carefully transferred into the membrane reactor. After the membrane had been thoroughly flushed by several $100 \mathrm{~mL}$ portions of $\mathrm{CH}_{2} \mathrm{Cl}_{2}$, the reactants (ethylene solution $1.8 \mathrm{M}$ in $\mathrm{CH}_{2} \mathrm{Cl}_{2}$, flow rate $2.5 \mathrm{mLh}^{-1}$; styrene solution $10 \mathrm{M}$ in $\mathrm{CH}_{2} \mathrm{Cl}_{2}$, flow rate $2.5 \mathrm{mLh}^{-1}$ ) were pumped through the reactor. The catalyst sol ution $(0.05 \mathrm{mmol}$ in $2 \mathrm{~mL}$ of $\mathrm{CH}_{2} \mathrm{Cl}_{2}$ ) was injected via an HPLC injection valve. Samples of the outcoming product solution were taken continuously and analyzed by GC.

Acknowledgment. The authors thank Mrs. A. van der Kerk and $\mathrm{Mr}$. K. Versluis from the Analytical Chemical Department for measuring the FAB-MS spectra. Dr. J . Verweij (DSM/Gist) and Prof. J . G. de Vries (DSM) are kindly acknowledged for stimulating discussions. Prof. D. Vogt and E. Eggeling thank Prof. W. Keim from the Institute of Technical and Macromolecular Chemistry (ITMC) of the RWTH Aachen for excellent working conditions. Mr. S. Schwerdt (RWTH Aachen) is gratefully acknowledged for his contributions to the construction of the membrane reactor. This work was 
supported by the Council for Chemical Sciences of The Netherlands Organization for Scientific Research (CW-NWO), the Dutch Technology F oundation (STW) with financial aid from DSM Gist, and the Deutsche Forschungsgemeinschaft (DFG, SFB 380).
Supporting Information Available: Experimental part with all NMR peak assignments. This material is available free of charge via the Internet at http://pubs.org.org. 